\title{
Direitos de propriedade intelectual e comércio exterior de serviços do Brasil no período de 2014 a 2018
}

\author{
Araken Alves de Lima* \\ Alisson Luiz Lessak** \\ Alejandro Knaesel Arrabal*** \\ Mauro Catharino Vieira da Luz**** \\ Bruna Luiza Gonçalves*****
}

\section{Resumo}

Este artigo apresenta panorama brasileiro das operações sobre direitos de propriedade intelectual no comércio exterior de serviços, a partir dos dados do Sistema Integrado de Comércio Exterior de Serviços, Intangíveis e Outras Operações que Produzam Variações no Patrimônio, 2014 a 2018, e do Balanço de Pagamentos, 1995 a 2020. Utilizou-se de indicadores de comércio internacional para explicitar a participação do Brasil nos processos de trocas internacionais, em especial nas operações sobre direitos de propriedade intelectual. O resultado indica o baixo efeito das políticas de apoio e estímulo à inovação e à propriedade intelectual no Brasil no seu padrão de inserção comercial aos mercados globais.

Palavras-chave: Direitos de Propriedade Intelectual; Comércio Exterior de Serviços;

\section{Intellectual property rights and foreign trade in services in Brazil from 2014 to 2018}

\begin{abstract}
This article presents the Brazilian panorama of operations on intellectual property rights in the foreign trade of services, based on the data available on the Integrated System of Foreign Trade in Services, Intangibles and Other Operations that Produce Changes in Assets, 2014 to 2018, and of the Balance of Payments, 1995 to 2020. International trade indicators were used Brazil's participation in international exchange processes, special in operations on intellectual property rights. The result indicates the low effect of the policies to support and encourage innovation and intellectual property in Brazil in its pattern of commercial insertion in global markets.
\end{abstract}

Keywords: Intellectual Property Rights; Foreign Trade in Services;

Classificação JEL: 034; P45

\footnotetext{
* Economista. Instituto Nacional da Propriedade Industrial (INPI). Professor nos Programas de Mestrado e Doutorado Profissional em Propriedade Intelectual e Inovação do INPI e de Mestrado Profissional em Propriedade Intelectual e Transferência de Tecnologia para Inovação (PROFNIT) da Universidade Federal de Santa Catarina (UFSC). E-mail: araken@inpi.gov.br

** Mestre em Propriedade Intelectual e Transferência de Tecnologia para a Inovação (PROFNIT/UFSC)

e Doutorando no Programa de Pós-Graduação de Engenharia e Gestão do Conhecimento (EGC/UFSC).

E-mail: alissonll@gmail.com

***Professor dos Programas de Mestrado em Direito (PPGD) e Administração (PPGAd) da Fundação Universidade Regional de Blumenau (FURB). Membro da Agência de Inovação Tecnológica da FURB.

E-mail: arrabal@furb.br

***Economista do (INPI). Professor nos Programas de Mestrado e Doutorado Profissional em Propriedade Intelectual e Inovação do INPI. E-mail: mauroluz@ inpi.gov.br

*****Bacharel em Comércio Exterior. Universidade Federal de Santa Catarina (UFSC). Mestranda no PROFNIT/UFSC. E-mail: bluizagoncalves@gmail.com
} 


\section{Introdução}

Um dos fatores que caracteriza o que se convencionou chamar de globalização é o crescimento da importância do comércio internacional. Isso quer dizer, tanto o volume de transações quanto o envolvimento de um número cada vez maior de países em operações comerciais, sejam circulação de bens, contratação de serviços ou movimento de capitais, que se sustentam em regulamentações e normas estipuladas em acordos internacionais. É certo que o comércio internacional é uma marca da formação e avanço das civilizações, a Rota da Seda, caminhos de comércio que interconectavam o Oriente e a Europa desde os anos 200 a.C., é uma constatação disso. No entanto, o progresso tecnológico observado principalmente a partir do último quarto do século XX e seus reflexos nos setores de transportes, comunicações e na indústria em geral promoveu enorme diversificação nos itens transacionados entre as nações, transformou as cadeias produtivas e intensificou a interdependência entre as economias.

A interação entre os países no âmbito do comércio internacional fica bem evidenciada na balança comercial, onde se contabilizam os fluxos de exportações e importações de uma economia. A balança comercial, portanto, é um importante indicador de desempenho da economia ao revelar o resultado desses fluxos comerciais. Se um país exporta mais que importa, seu saldo é positivo e a economia é considerada superavitária nas relações comerciais com o exterior. Caso contrário, importar mais que exportar caracteriza uma economia deficitária, já que seu saldo comercial com o exterior é negativo ${ }^{1}$. E mais, a balança comercial, também, ilustra o volume da corrente de comércio pois a soma das exportações com as importações revela o total de comércio transacionado por um país com o exterior. E ainda, a corrente de comércio, quando confrontada com o valor de todos os bens e serviços produzidos no referido país, ou seja, seu Produto Interno Bruto (PIB), revela o grau de abertura comercial do país ao comércio internacional. Este, portanto, constitui-se num indicador da intensidade das relações comerciais entre países e regiões, na medida em que expõe o quanto as trocas comerciais de um determinado país com o resto do mundo representam percentualmente em relação à riqueza criada internamente.

Outro indicador muito importante que se deduz dos dados da balança comercial é o conceito de taxa de cobertura, que resulta da relação entre os valores das exportações e os das importações. Com isso, se calcula o quanto a receita com exportações financiou as despesas com importações. Se o resultado encontrado foi abaixo dos 100\%, significa que as receitas com exportações não foram suficientes ao país para pagar as despesas incorridas com as importações de

\footnotetext{
${ }^{1}$ Sobre o assunto, recomenda-se a consulta da obra "Economia internacional” de Krugman e Obstfeld (2005).
} 
outros países. Um resultado acima de 100\% revela que as exportações são superavitárias, isto é, pagaram as importações e ainda houve algum saldo positivo. Ou, ainda, pode haver uma situação de equilíbrio que é o caso de os valores de exportações e importações se igualarem. A balança comercial, contudo, não contém as informações de todas as interações da economia de um país com os demais países. Além das operações que envolvem exportações e importações de bens, há também o fluxo de serviços e outros registros de valores relacionados aos juros, dividendos, salários e transferências unilaterais, e ainda os registros das transações envolvendo investimentos, empréstimos e financiamentos que os países fazem entre si, denominados como movimento de capitais $^{2}$. Tudo isso vem a compor a peça fundamental da contabilidade de um país que é o balanço de pagamentos.

Nos limites do que está acordado no âmbito do comércio internacional por meio de regras discutidas e implementadas em órgãos multilaterais, como a Organização Mundial do Comércio (OMC), os blocos regionais ou mesmo os acordos bilaterais, os países especificamente estabelecem suas próprias políticas de comércio exterior. Estas são reguladas por suas legislações internas, como legislação aduaneira, de meio ambiente, de propriedade intelectual, ou outras, para estabelecer formas de intercâmbio com o resto do mundo para favorecer seus próprios interesses nas relações comerciais internacionais.

O Brasil, historicamente, registra uma balança comercial superavitária, especializada em mercadorias de baixo valor agregado, e sem grandes alterações no seu perfil comercial nos últimos 40 anos (ABREU, 2014). Por outro lado, é um grande importador de serviços, operando continuamente num padrão altamente deficitário. A conta de serviços do balanço de pagamentos é composta por um conjunto variado de itens, incluindo os serviços de transportes; as viagens internacionais; os serviços de construção; seguros; educação; serviços financeiros; serviços de propriedade intelectual; serviços de telecomunicação, computação e informação; serviços de aluguel de equipamentos; outros serviços de negócio, inclusive arquitetura e engenharia; serviços culturais, pessoais e recreativos; além dos serviços governamentais.

Em relação a categoria "serviços de propriedade intelectual”, objeto principal deste artigo, optou-se por substituí-la por “operações sobre direitos de propriedade intelectual”. Como se verá mais adiante, a propriedade intelectual não implica diretamente em "serviços", mas em "bens" de natureza intangível ${ }^{3}$ cujas operações imediatas produtoras de variação patrimonial compreendem

\footnotetext{
${ }^{2}$ Para uma completa apresentação e descrição dos conceitos básicos e interpretações da contabilidade social, ver "A nova contabilidade social" de Paulani e Braga (2007).

${ }^{3}$ Sobre o assunto, recomenda-se a leitura do artigo "Estatuto ontológico dos objetos de propriedade intelectual" de Arrabal e Arrabal (2020).
} 
contratos de licenciamento, de cessão ou congêneres sobre "direitos de propriedade intelectual", considerados esses direitos, por definição normativa, "bens móveis".

A propriedade intelectual é de reconhecida relevância no contexto de mudanças estruturais pelas quais a economia mundial vem passando desde finais do século XX. Isso pode ser constatado pela própria criação da OMC que tem dentre seus principais tratados de fundação um que diz respeito à propriedade intelectual, o Acordo sobre Aspectos dos Direitos de Propriedade Intelectual relacionados ao Comércio (conhecido como Acordo TRIPS). Este foi um dos fatores que justificaram a escolha do tema deste artigo. Mas, não só isso, também deve ser destacada a oportunidade disponibilizada numa base de dados com informações detalhadas dos registros de vendas e aquisições de serviços e intangíveis entre o Brasil e o resto do mundo, revelando um importante fluxo financeiro relacionado ao comércio exterior de serviços. Trata-se, no caso, do Sistema Integrado de Comércio Exterior de Serviços, Intangíveis e Outras Operações que Produzam Variações no Patrimônio (Siscoserv), um sistema de coleta e classificação de informações do comércio exterior de serviços e operações patrimoniais que foi construído com base na Central Product Classification (CPC), versão 2.0, desenvolvida pela Organização das Nações Unidas ${ }^{4}$.

Assim, o artigo ora apresentado trata do comércio exterior de serviços do Brasil com foco nas operações sobre direitos de propriedade intelectual a partir da descrição e análise dos dados disponibilizados pelo Siscoserv para o período de 2014 a 2018. Uma vez que tais dados têm um nível de detalhamento que engloba valores, destinos, origens e itens transacionados por Unidade da Federação, importa apresentar aqui, além do desempenho geral do país, a performance dos vários Estados revelando quem compra e quem vende propriedade intelectual e em que escala.

Para isso, o artigo conta, além dessa introdução, com uma seção de contextualização do comércio exterior de serviços tendo como base os dados do balanço de pagamentos do Brasil, mas, dando destaque para as operações sobre direitos de propriedade intelectual. A seção seguinte trata do conceito de propriedade intelectual para apresentar a caracterização dos bens e respectivos direitos de propriedade intelectual que são objeto de operações patrimoniais no comércio internacional. Na seção seguinte, apresenta-se a principal base de dados utilizada, o Siscoserv e a $\mathrm{NBS}^{5}$, de modo a detalhar a origem dos dados, sua forma de organização, abrangência e limitações. Também compõe o artigo, uma seção explicitando os passos metodológicos implementados para

\footnotetext{
${ }^{4}$ Esses dados foram divulgados pela Secretaria de Comércio Exterior do governo federal (BRASIL, 2021) como parte do trabalho que resultou na criação da Nomenclatura Brasileira de Serviços, Intangíveis e Outras Operações que Produzam Variações no Patrimônio (NBS) e que, colocado em funcionamento de 2012 a 2019, coletou e divulgou um conjunto relevante de dados sobre as interações do Brasil com o resto do mundo no que se refere ao comércio exterior de serviços.

${ }^{5}$ Nomenclatura Brasileira de Serviços, Intangíveis e Outras Operações que Produzam Variações no Patrimônio (NBS)
} 
organizar os dados coletados e analisados. Na sequência, uma seção para discussão dos resultados encontrados. Por fim, são apresentadas as considerações finais pontuando discussões que precisam ser desenvolvidas a partir dos resultados aqui apresentados.

\section{Contexto geral do comércio exterior de serviços do Brasil e as operações sobre direitos de propriedade intelectual no período 1995 a 2020}

Em consulta ao Sistema Gerenciador de Séries Temporais do Banco Central do Brasil para levantar dados sobre o saldo anual de serviços registrados no balanço de pagamentos para o período de 1995 a 2020, verificou-se um contínuo e aprofundado déficit iniciando em US\$ 7,02 bilhões no começo da série, passando por US\$ 48,24 bilhões em 2014, e chegando a US\$20,63 bilhões em 2020, conforme o Gráfico 1.

Gráfico 1: Percentual do déficit das operações sobre propriedade intelectual em relação ao total do déficit de serviços entre 1995 e 2020.



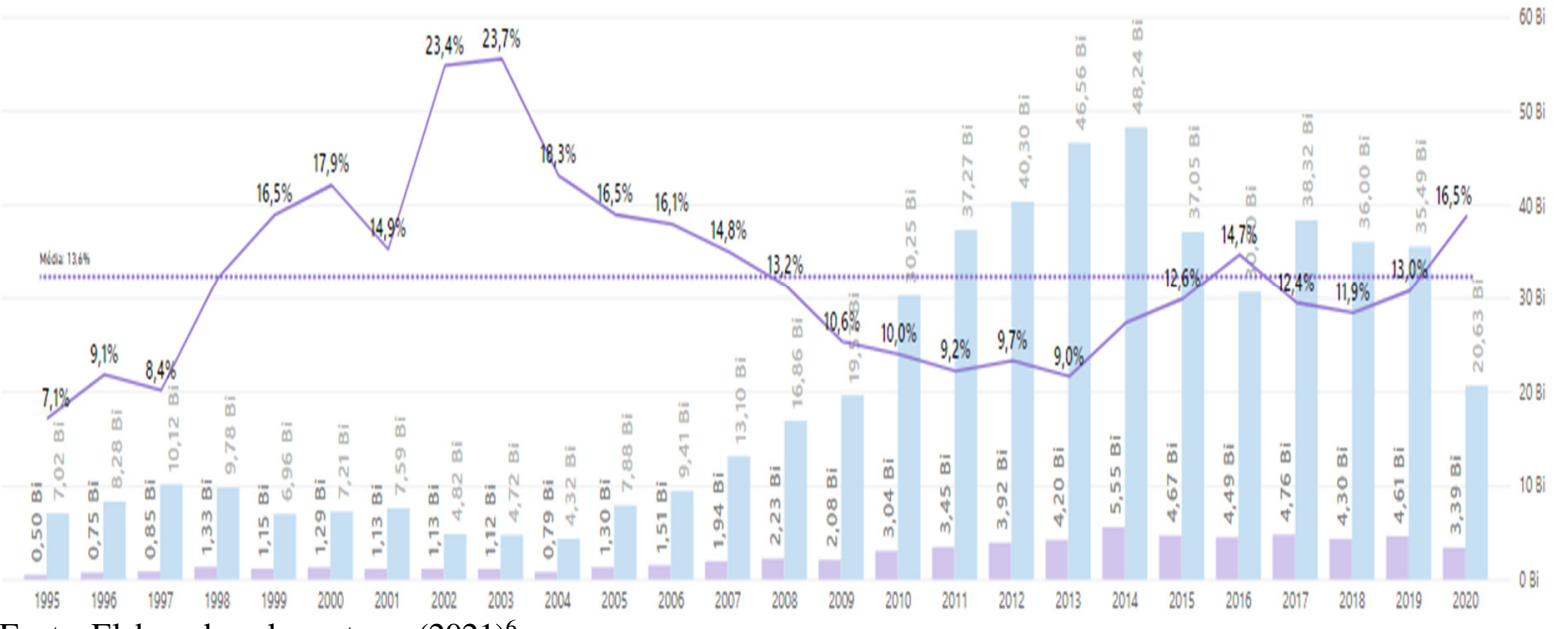

Fonte: Elaborado pelos autores (2021) .

O interesse deste artigo é analisar um item específico do comércio de serviços do Brasil, as operações sobre direitos de propriedade intelectual. Este item, conforme Gráfico 1, também tem apresentado déficit estrutural em todo o período da série 1995-2020 do balanço de serviços, variando em torno da média de $13,6 \%$, mas, tendo chegado a representar $23,7 \%$ do déficit total da conta de serviços, em 2003.

Chama a atenção na representação gráfica, o comportamento da linha de déficit das operações sobre propriedade intelectual em relação ao déficit total de serviços. O padrão visual do

\footnotetext{
${ }^{6}$ Gráfico elaborado a partir dos dados disponibilizados pelo SGS - Sistema Gerenciador de Séries Temporais v2.1 (BANCO CENTRAL DO BRASIL, 2021).
} 
período mostra a maior presença da propriedade intelectual no déficit total do comércio de serviços, quando este diminui e o inverso quando ele aumenta. Não é objetivo do presente artigo apresentar estudos estatísticos mais detalhados sobre a dispersão dos referidos dados, no entanto, merece ser observada a possível inelasticidade das operações sobre direitos de propriedade intelectual no comércio exterior do Brasil. O movimento de redução/aumento do déficit dos serviços totais obviamente está relacionado com as operações de aumento/redução das exportações e/ou das importações de serviços pelo Brasil, fator que, no entanto, não deve estar afetando as operações sobre direitos de propriedade intelectual. Ou seja, a capacidade de substituir as importações de direitos de propriedade intelectual parece ser baixa, o que torna evidente a contribuição da propriedade intelectual para a consolidação de um padrão consistente de corrente de comércio de serviços deficitária, cujos detalhes serão apresentados em seção adiante.

A performance das operações sobre direitos de propriedade intelectual no comércio exterior do Brasil pode ser entendida por meio do indicador grau de abertura ao mercado internacional, dado pela razão entre a corrente de comércio do país, setor ou região específica e o PIB. Para esse indicador, quanto maior a percentagem da relação corrente de comércio/PIB, maior é o grau de abertura da economia, região ou setor ao mercado externo. Essa medida, para o caso brasileiro, está apresentada no Gráfico 2 e tem variado em torno de 0,21\% no período 1995-2020. Entretanto, faz-se necessário a consideração de que o grau de abertura não é um conceito absoluto. Ou seja, por si só, nada significa. O ideal é que a medida encontrada seja interpretada em termos comparativos com outros países. Como não se dispõe ainda desses elementos para uma apreciação mais adequada, a análise aqui apresentada se limitará a implementação do referido conceito aos dados das operações sobre direitos de propriedade intelectual do Brasil exclusivamente, o que se fará associada aos conceitos complementares de Esforço Exportador (valores exportados/PIB) e Dependência das Importações (valores das despesas com importação/PIB). Dessa forma, se identificará o grau de abertura do Brasil ao comércio internacional de direitos de propriedade intelectual em sua evolução no período analisado, o que permitirá comparações intertemporais para o caso brasileiro.

Observando a longa linha referente ao grau de abertura do Brasil ao comércio internacional de direitos de propriedade intelectual, vê-se que tais operações apresentam uma trajetória ascendente expressiva. Sem levar em consideração os variados contextos e processos econômicos que marcaram o período em foco, o fato é que as operações sobre direitos de propriedade intelectual com o exterior saíram de um patamar de $0,07 \%$ para $0,32 \%$, um crescimento da ordem de $450 \%$. Numa comparação intertemporal, vê-se que há mudanças ascendentes e descendentes no comportamento desse indicador, no entanto, esse resultado diz pouco tendo em 
vista a ausência de dados de outros países para efetuar estudos comparativos. Por enquanto fica uma questão sem resposta: embora demonstre uma trajetória fortemente ascendente, esse indicador do grau de abertura do Brasil ao comércio internacional de direitos de propriedade intelectual, que não perfaz $0,5 \%$, é um valor significativo para esse tipo de atividade comercial com o exterior?

Gráfico 2: Esforço exportador, dependência das importações e grau de abertura do Brasil ao comércio internacional de direitos de propriedade intelectual.

- Essorço Exportador Depedencia das Importaçóes 1 Grau de Abertura do Brasil ao Comércio Internacional de Diretios de Propredade Intelectual

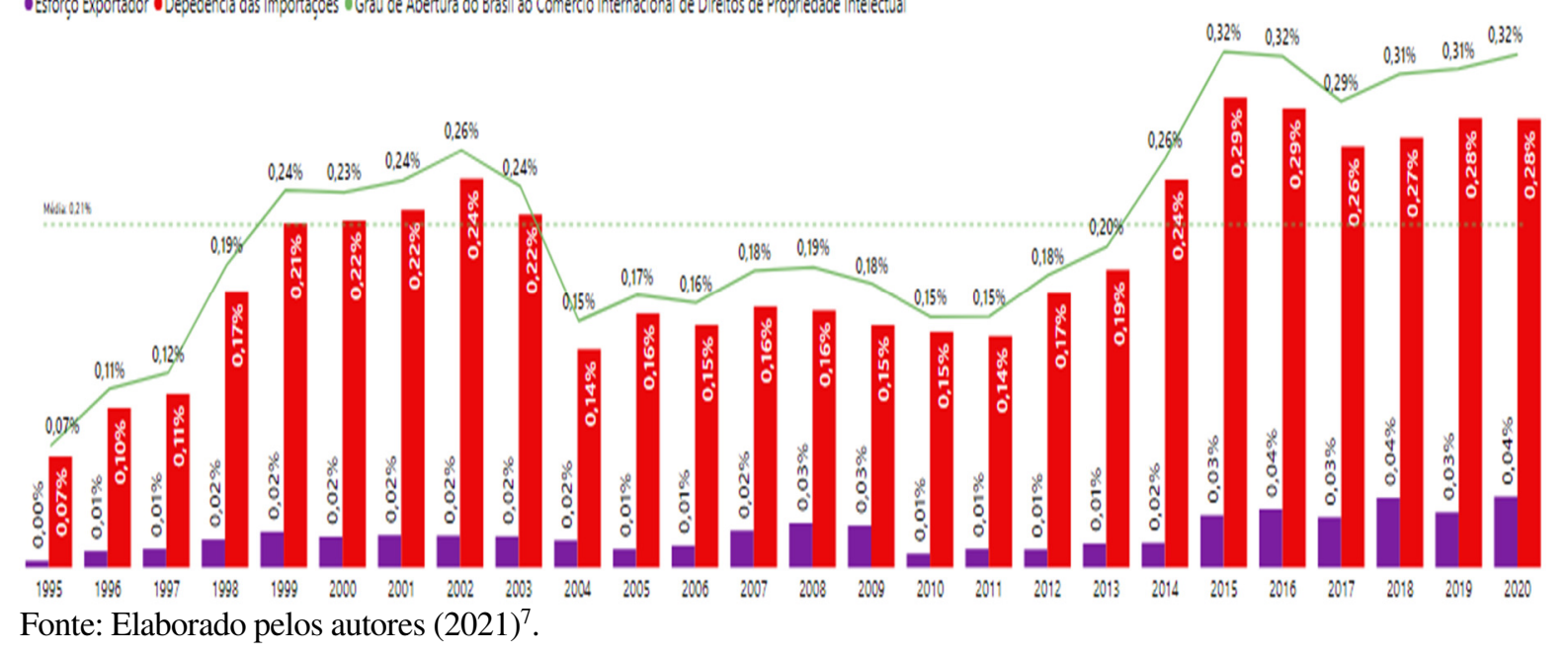

Ademais, outras duas informações apresentadas no Gráfico 2 são reveladoras do padrão de evolução do grau de abertura ao mercado internacional sobre direitos de propriedade intelectual pelo Brasil. O baixíssimo Esforço Exportador, representado pela barra roxa do gráfico, chegando ao máximo de $0,04 \%$ e a forte Dependência das Importações, da ordem de 0,30\%, representada pela barra vermelha, mostram a insignificância de receitas oriundas de operações com direitos de propriedade intelectual de residentes do Brasil. O que esses indicadores apontam em relação ao grau de abertura apresentado é que seu comportamento ascendente esteve relacionado ao forte crescimento das importações de direitos de propriedade intelectual de residentes no exterior. $\mathrm{Ou}$ seja, a corrente de comércio de propriedade intelectual do Brasil é marcadamente definida pelas importações.

\section{Propriedade Intelectual}

A expressão "propriedade intelectual” é marcada por certa diversidade semântica que, não raro, dificulta sua adequada compreensão. De modo geral designa um segmento especializado do

\footnotetext{
${ }^{7}$ Gráfico elaborado a partir dos dados disponibilizados pelo SGS - Sistema Gerenciador de Séries Temporais v2.1 (BANCO CENTRAL DO BRASIL, 2021).
} 
Direito, entendido como um campo do conhecimento (BARBOSA, 2003; SILVEIRA, 2014). Nesse viés, Ascensão (2002) utiliza também o termo "direitos intelectuais".

Em uma perspectiva mais estrita, a propriedade intelectual refere-se a um ou mais "direitos" que incidem sobre determinadas criações humanas. Assim, a "propriedade" ou, o "direito de propriedade", compreende a garantia de domínio exclusivo (uso, fruição e disposição) de certos bens.

Um terceiro emprego da expressão propriedade intelectual refere-se aos "bens" sobre os quais incidem o direito de domínio. Nesse viés, é muito comum reconhecer que a principal característica dos bens de propriedade intelectual consiste na intangibilidade. Ocorre que nem todos os bens intangíveis são de natureza intelectual, a exemplo dos campos eletromagnéticos utilizados para a radiodifusão.

Observe-se que, do ponto de vista econômico, o que efetivamente se transfere são direitos e não exatamente os bens de natureza intelectual, dado o seu caráter intangível. Os bens de propriedade intelectual são intangíveis porque, de modo geral, eles não se confundem com os recursos e elementos materiais que lhe conferem suporte. Assim, um texto independe da tinta, do papel ou de plataformas digitais. Um invento não se reduz aos componentes ou substâncias materiais que o compõem, o que é ainda mais evidente na hipótese de invenções caracterizadas por processos. As marcas e as indicações geográficas não são redutíveis aos respectivos signos enquanto expressões gráficas em si. Para esses e os outros bens intelectuais, a exclusividade decorre da lei como forma de constituição de ativos importantes para a economia, de modo que ela estabelece condições e critérios específicos para a caracterização desses bens. Assim, não serão todos os produtos da criatividade humana sujeitos a direitos de propriedade intelectual.

Também é necessário entender que a legislação reconhece os "direitos intelectuais" como "bens móveis", portanto, suscetíveis de transferência por meio de operações de licenciamento, cessão ou congêneres. A licença confere ao seu titular o direito de exercer uma ou parcela das faculdades que compreendem a propriedade, considerando fins, condições e prazo estabelecidos pelas partes. Por sua vez, na cessão transfere-se a propriedade de forma integral, tornando o cessionário legítimo titular de todas as faculdades de domínio sobre o bem. Embora seja típico à licença o caráter limitado das faculdades conferidas ao licenciado, em contraposição ao ânimo

\footnotetext{
8 “Art. $3^{\circ}$ Os direitos autorais reputam-se, para os efeitos legais, bens móveis" (BRASIL, 1998a).; "Art. 5 Consideram-se bens móveis, para os efeitos legais, os direitos de propriedade industrial" (BRASIL, 1996); "Art. $2^{\circ} \mathrm{A}$ proteção dos direitos relativos à propriedade intelectual referente a cultivar se efetua mediante a concessão de Certificado de Proteção de Cultivar, considerado bem móvel para todos os efeitos legais e única forma de proteção de cultivares e de direito que poderá obstar a livre utilização de plantas ou de suas partes de reprodução ou de multiplicação vegetativa, no País" (BRASIL, 1997).
} 
universal da cessão, em ambos os casos, é possível que o contrato seja firmado em caráter temporário ou definitivo. Essas operações, entre outras análogas ao campo dos direitos de propriedade intelectual, como os contratos de Know-How e informações não divulgadas (segredo industrial ou de negócio), compreendem a base do Siscoserv.

Observe-se que, o Manual Siscoserv (BRASIL, 2018a, p. 28) incorre em sutil imprecisão terminológica quando literalmente considera como intangíveis para fins de registro na base:

[...] I - o licenciamento [...] e a cessão, temporária ou definitiva, dos direitos de propriedade intelectual [...] II - os contratos de transferência de tecnologia [...] III os contratos de franquia IV - a exploração dos recursos naturais e o licenciamento dos direitos sobre conhecimento tradicional; e V - o licenciamento dos direitos relativos ao acesso a recursos genéticos.

Com exceção da "exploração dos recursos naturais", o licenciamento e a cessão, que são contratos, assim como os contratos de transferência de tecnologia (envolvendo ou não Know-How) e de franquia, não correspondem a intangíveis per se, mas consistem nas operações que versam sobre intangíveis.

De semelhante modo, nota-se que a expressão "serviços de propriedade intelectual" adotada pelo Banco Central do Brasil, indica uma imprecisão terminológica dado que direitos de propriedade intelectual não são "serviços" no sentido mais estrito do termo. Serviços são atividades em regra sujeitas a retribuição econômica. Por sua vez, direitos são garantias, conferidas por lei a determinados agentes econômicos (pessoas físicas ou jurídicas), direitos estes que podem ser objeto de transferência, também sujeita a retribuição econômica (nesse caso, popularmente denominado "royalty"). Assim, contratos de licença ou cessão de direitos de propriedade intelectual apresentam natureza jurídica distinta dos contratos de prestação de serviços, ainda que de forma muito genérica, ambas figurem como operações econômicas sobre "intangíveis", ou ainda, sejam os contratos reconhecidos eles mesmos como intangíveis.

Considerado o quadro normativo nacional, integram o universo dos bens intangíveis sujeitos à direitos de propriedade intelectual: as obras literárias, artísticas e científicas e outras expressões humanas análogas; as interpretações e execuções, os fonogramas e as emissões de radiodifusão (BRASIL, 1998 ); os programas de computador (BRASIL, 1998b); as invenções, os modelos de utilidade, os desenhos industriais e as indicações geográficas (BRASIL, 1996); as cultivares (BRASIL, 1997); a topografia de circuitos integrados (BRASIL, 2007); e os conhecimentos tradicionais associados a recursos genéticos (BRASIL, 2015). Segue um quadro panorâmico que descreve os bens e respectivos direitos de propriedade intelectual vinculados. 
Quadro 1 - Panorama dos bens e direitos de propriedade intelectual

\begin{tabular}{|c|c|c|}
\hline Legislação & Bens de propriedade intelectual & Direitos de propriedade intelectual \\
\hline \multirow{4}{*}{$\begin{array}{l}\text { Lei }{ }^{\circ} \\
9.610 / 98\end{array}$} & $\begin{array}{c}\text { Obras literárias, artísticas e científicas } \\
\text { e expressões análogas }\end{array}$ & $\begin{array}{l}\text { "Cabe ao autor o direito exclusivo de utilizar, fruir e dispor da obra } \\
\text { literária, artística ou científica." (art. 28) } \\
\text { "Os direitos patrimoniais do autor perduram por setenta anos contados } \\
\text { de } 1^{\circ} \text { de janeiro do ano subsequente ao de seu falecimento, obedecida a } \\
\text { ordem sucessória da lei civil." (art. } 41 \text { ). } \\
\text { "O prazo de proteção aos direitos patrimoniais sobre obras audiovisuais } \\
\text { e fotográficas será de setenta anos, a contar de } 1^{\circ} \text { de janeiro do ano } \\
\text { subsequente ao de sua divulgação." (art. 44) }\end{array}$ \\
\hline & Interpretações e execuções & $\begin{array}{l}\text { "Tem o artista intérprete ou executante o direito exclusivo de, a título } \\
\text { oneroso ou gratuito, autorizar ou proibir" qualquer "modalidade de } \\
\text { utilização de suas interpretações ou execuções." (art. 90) } \\
\text { "É de setenta anos o prazo de proteção aos direitos conexos, contados a } \\
\text { partir de } 1^{\circ} \text { de janeiro do ano subsequente [...] à execução e representação } \\
\text { pública [...]" para as interpretações e execuções (art. 96) }\end{array}$ \\
\hline & Fonogramas & $\begin{array}{l}\text { "O produtor de fonogramas tem o direito exclusivo de, a título oneroso } \\
\text { ou gratuito, autorizar-lhes ou proibir-lhes" quaisquer "modalidades } \\
\text { de utilização, existentes ou que venham a ser inventadas." (art. 93) } \\
\text { "É de setenta anos o prazo de proteção aos direitos conexos, contados a } \\
\text { partir de } 1^{\circ} \text { de janeiro do ano subsequente à fixação, para os fonogramas } \\
\text { [...]" (art. 96) }\end{array}$ \\
\hline & Emissões de radiodifusão & $\begin{array}{l}\text { "Cabe às empresas de radiodifusão o direito exclusivo de autorizar ou } \\
\text { proibir a retransmissão, fixação e reprodução de suas emissões, bem } \\
\text { como a comunicação ao público, pela televisão, em locais de frequência } \\
\text { coletiva, sem prejuízo dos direitos dos titulares de bens intelectuais } \\
\text { incluídos na programação." (art. 95) } \\
\text { "É de setenta anos o prazo de proteção aos direitos conexos, contados a } \\
\text { partir de } 1^{\circ} \text { de janeiro do ano subsequente [...] à transmissão, para as } \\
\text { emissões das empresas de radiodifusão [...]" (art. 96) }\end{array}$ \\
\hline $\begin{array}{c}\text { Lei } n^{o} \\
9.609 / 98\end{array}$ & Programas de computador & $\begin{array}{l}\text { "O regime de proteção à propriedade intelectual de programa de } \\
\text { computador é o conferido às obras literárias [...] observado o disposto } \\
\text { nesta Lei." (art. 2) } \\
\text { "Fica assegurada a tutela dos direitos relativos a programa de } \\
\text { computador pelo prazo de cinquenta anos, contados a partir de } 1^{\circ} \text { de } \\
\text { janeiro do ano subsequente ao da sua publicação ou, na ausência desta, } \\
\text { da sua criação." (art. } 2, \S 2^{\circ} \text { ) }\end{array}$ \\
\hline
\end{tabular}

"A patente [de invenção e de modelo de utilidade] confere ao seu titular

Invenções $\quad$ o direito de impedir terceiro, sem o seu consentimento, de produzir, usar, colocar à venda, vender ou importar com estes propósitos: I produto objeto de patente; II - processo ou produto obtido diretamente por processo patenteado." (art. 42)

"A patente de invenção vigorará pelo prazo de 20 (vinte) anos e a de

Modelos de utilidade modelo de utilidade pelo prazo 15 (quinze) anos contados da data de depósito." (art. 40)

"Ao autor será assegurado o direito de obter registro de desenho industrial que lhe confira a propriedade [...]" (art. 94)

Desenhos industriais "O registro vigorará pelo prazo de 10 (dez) anos contados da data do depósito, prorrogável por 3 (três) períodos sucessivos de 5 (cinco) anos cada." (art. 108).

Lei $n^{\circ}$

"A propriedade da marca adquire-se pelo registro validamente

9.279/96 expedido, conforme as disposições desta Lei, sendo assegurado ao titular seu uso exclusivo em todo o território nacional [...]" (art. 129)

"Ao titular da marca ou ao depositante é ainda assegurado o direito de: I

Marcas - ceder seu registro ou pedido de registro; II - licenciar seu uso; III zelar pela sua integridade material ou reputação." (art. 130)

"O registro da marca vigorará pelo prazo de $10(\mathrm{dez})$ anos, contados da data da concessão do registro, prorrogável por períodos iguais e sucessivos." (art. 133)

"O uso da indicação geográfica é restrito aos produtores e

Indicações geográficas prestadores de serviço estabelecidos no local, exigindo-se, ainda, em relação às denominações de origem, o atendimento de requisitos de qualidade." (art. 182) 


\begin{tabular}{|c|c|c|}
\hline $\begin{array}{l}\text { Lei n }^{\circ} \\
9.456 / 97\end{array}$ & Cultivares & $\begin{array}{l}\text { "A proteção assegura a seu titular o direito à reprodução comercial no } \\
\text { território brasileiro, ficando vedados a terceiros, durante o prazo de } \\
\text { proteção, a produção com fins comerciais, o oferecimento à venda ou a } \\
\text { comercialização, do material de propagação da cultivar, sem sua } \\
\text { autorização." (art. } 9^{\circ} \text { ) } \\
\text { "A proteção da cultivar vigorará, a partir da data da concessão do } \\
\text { Certificado Provisório de Proteção, pelo prazo de quinze anos, } \\
\text { excetuadas as videiras, as árvores frutíferas, as árvores florestais e as } \\
\text { árvores ornamentais, inclusive, em cada caso, o seu porta-enxerto, para } \\
\left.\text { as quais a duração será de dezoito anos." (art. } 11^{\circ}\right)\end{array}$ \\
\hline $\begin{array}{c}\text { Lei }^{\circ} \\
11.484 / 07\end{array}$ & Topografia de circuitos integrados & $\begin{array}{l}\text { "O registro de topografia de circuito integrado confere ao seu titular o } \\
\text { direito exclusivo de explorá-la, [...]" (art. 36) } \\
\text { "A proteção da topografia será concedida por } 10 \text { (dez) anos contados da } \\
\text { data do depósito ou da } 1^{\text {a }} \text { (primeira) exploração, o que tiver ocorrido } \\
\text { primeiro." (art. 35) }\end{array}$ \\
\hline $\begin{array}{c}\text { Lei }^{\circ} \\
13.123 / 15\end{array}$ & $\begin{array}{l}\text { Conhecimentos tradicionais } \\
\text { associados a recursos genéticos }\end{array}$ & $\begin{array}{l}\text { "Às populações indígenas, às comunidades tradicionais e aos } \\
\text { agricultores tradicionais que criam, desenvolvem, detêm ou conservam } \\
\text { conhecimento tradicional associado são garantidos os direitos de: I - } \\
\text { ter reconhecida sua contribuição para o desenvolvimento e conservação } \\
\text { de patrimônio genético, em qualquer forma de publicação, utilização, } \\
\text { exploração e divulgação; II - ter indicada a origem do acesso ao } \\
\text { conhecimento tradicional associado em todas as publicações, utilizações, } \\
\text { explorações e divulgações; III - perceber benefícios pela exploração } \\
\text { econômica por terceiros, direta ou indiretamente, de conhecimento } \\
\text { tradicional associado, nos termos desta Lei; [...]" (art. 10). }\end{array}$ \\
\hline
\end{tabular}

Fonte: Elaborado pelos autores (2021)

Todos os direitos de propriedade intelectual acima apresentados (com exceção das especificidades relacionadas as marcas, indicações geográficas e conhecimentos tradicionais) são destinados aos respectivos autores/inventores por previsão constitucional ${ }^{9}$. Porém, esses direitos poderão ser titularizados por outras pessoas, físicas ou jurídicas, mediante manifestação de vontade do autor/inventor, por sucessão hereditária ou em decorrência de relação de emprego, nos termos e condições previstos na legislação.

Aos autores também são reconhecidos direitos morais, entendidos como garantias relacionadas a sua reputação e imagem. Embora previstos especialmente na lei de direitos autorais (BRASIL, 1998), o reconhecimento da condição de autor/inventor e os respectivos desdobramentos relacionados a reputação e imagem, alcançam a realidade de praticamente todos os bens de propriedade intelectual. Diferente do que ocorre com os direitos de uso, fruição e disposição (também conhecidos como direitos patrimoniais), os direitos morais não podem ser transferidos.

Como já mencionado, a lei estabelece as condições para a caracterização dos bens de propriedade intelectual. Tal caracterização é necessária dado que é a partir dela que se torna juridicamente possível exercer direitos de propriedade intelectual e, por consequência, transferi-los.

\footnotetext{
9 “Art. $5^{\circ}$ [...] XXVII - aos autores pertence o direito exclusivo de utilização, publicação ou reprodução de suas obras, transmissível aos herdeiros pelo tempo que a lei fixar; [...] XXIX - a lei assegurará aos autores de inventos industriais privilégio temporário para sua utilização, bem como proteção às criações industriais, à propriedade das marcas, aos nomes de empresas e a outros signos distintivos, tendo em vista o interesse social e o desenvolvimento tecnológico e econômico do País" (BRASIL, 1988).
} 
Assim, a "obra" para efeito de direitos autorais, é criação do espírito, expressa por qualquer meio ou fixada em qualquer suporte, tangível ou intangível, conhecido ou que se invente no futuro (BRASIL, 1998a, art. $7^{\circ}$ ). No campo industrial, a invenção patenteável pressupõe um produto ou processo novo, que resulte de atividade inventiva e seja aplicável à indústria (BRASIL, 1996, art. $8^{\circ}$ ). A patente de modelo de utilidade exige ato inventivo que promova nova forma ou disposição de um objeto de uso prático, ou parte dele, resultando em melhoria no seu uso ou na fabricação (BRASIL, 1996, art. 9). O desenho industrial registrável, por sua vez, caracteriza-se como "a forma plástica ornamental de um objeto ou o conjunto ornamental de linhas e cores que possa ser aplicado a um produto, proporcionando resultado visual novo e original na sua configuração externa e que possa servir de tipo de fabricação industrial.” (BRASIL, 1996, art. 95). Para o registro de marca, exige-se um sinal visualmente perceptível cuja vinculação a um produto ou a um serviço permita distingui-los de outros do mesmo gênero. (BRASIL, 1996, art. 122). Assim, também para as indicações geográficas, cultivares, topografias de circuitos integrados e conhecimentos tradicionais associados a recursos genéticos, a legislação estabelece condicionantes que determinam a caracterização de cada um desses bens intelectuais.

\section{Sistema Integrado de Comércio Exterior de Serviços, Intangíveis e Outras Operações que Produzam Variações no Patrimônio (Siscoserv) e Nomenclatura Brasileira de Serviços (NBS)}

Elaborado pelo Governo Federal, o Siscoserv foi uma ferramenta informatizada para o desenvolvimento de ações de fomento, concepção, auxílio e verificação de políticas públicas relacionadas a serviços e intangíveis bem como para a orientação de estratégias empresariais de comércio exterior de serviços e intangíveis (BRASIL, 2018a). Por meio de um processo de gestão conjunta da Secretaria de Comércio e Serviços do antigo Ministério da Indústria, Comércio Exterior e Serviços - SCS/MDIC e da Secretaria da Receita Federal do Brasil do Ministério da Fazenda RFB/MF, tendo sido instituído pela Lei $\mathrm{n}^{\circ}$ 12.546, de 14 de dezembro de 2011, esse sistema tornava possível a análise legal, cambial, tributária e fiscal das operações comerciais de serviços com o exterior (BRASIL, 2011).

O Siscoserv foi criado em conformidade com as diretrizes do Acordo Geral sobre Comércio de Serviços (GATS) da OMC e foi aprovado pelo Decreto Legislativo ${ }^{\circ} 30$, de 15 de dezembro de 1994, e promulgado pelo Decreto no 1.355, de 30 de dezembro de 1994 (BRASIL, 2018a). Dessa forma, ele permitia o registro de operações comerciais estabelecendo uma divisão entre serviços ligados a mercadorias e serviços puros, seguindo uma padronização internacional 
para classificar os serviços com uma descrição pormenorizada criando a Nomenclatura Brasileira de Serviços, Intangíveis e outras Operações que Produzam Variações no Patrimônio (NBS).

Este sistema se conectava a outros órgãos do governo visando a captação de dados estatísticos que possibilitassem, dentre outras coisas, a fiscalização tributária. $\mathrm{O}$ acesso ao sistema estava disponível por meio eletrônico no Centro Virtual de Atendimento ao Contribuinte (e-CAC) da Receita Federal do Brasil, assim como no sítio da própria Secretaria de Comércio e Serviços (SCS). Subsidiariamente, o sistema de informações do Banco Central (SISBACEN) fornecia apoio e orientações referentes aos meios/formas de pagamentos (cartão de crédito, câmbio, TED), enquanto a Receita Federal, responsável pelo recolhimento dos tributos incidentes no comércio exterior, estabelecia prazos para registros das operações de comércio exterior (até 3 meses) além de estipular multas quanto a lançamentos fora do prazo ou não lançamento.

As informações transmitidas no Siscoserv eram fundamentais para amparar outros sistemas eletrônicos da administração pública que contribuíssem para a estruturação de política de comércio exterior de serviços; aprimoramento das ações para estímulo, formulação, acompanhamento e aferição das políticas públicas relacionadas a serviços e intangíveis; fortalecimento da participação do país nos fluxos internacionais de comércio de serviços; orientação às estratégias empresariais de comércio exterior de serviços e intangíveis por meio da viabilização de ferramentas de inteligência comercial.

Os destinatários do Siscoserv eram os residentes e domiciliados no Brasil que estabeleciam transações de venda ou aquisição de serviços com residentes ou domiciliados no exterior. Durante as etapas de negociação comercial, um conjunto de informações e documentos eram requeridas até a formalização da operação, incluindo comunicação via $e$-mails com clientes, inventores, parceiros, a respeito da classificação fiscal do serviço, intangível ou operação que produzia variação no patrimônio.

Destacam-se como fundamentais para exportação de serviços na fase de comercialização a Fatura Proforma ou orçamento e a Fatura Comercial ou Commercial Invoice como documentos de formalização de venda. Nesses documentos, devem constar dados referentes a empresa estrangeira (nome, número de identificação fiscal - NIF, endereço, país, vínculo) e dados do serviço (descrição do serviço, intangível ou outra variação no patrimônio de acordo com a NBS; data, moeda, valor, enquadramento).

Outro documento complementar é o contrato de compra e venda internacional que se refere a transferência de tecnologia e que deve ser averbado no Instituto Nacional da Propriedade Industrial (INPI). As averbações garantem os direitos de terceiros de boa-fé envolvidos nas transações e asseguram a remessa de pagamentos ao exterior, operação exclusivamente autorizada 
pelo Banco Central do Brasil (BCB) por meio de comprovação da averbação do contrato. Elas também salvaguardam a dedutibilidade das despesas com royalties relativas ao contrato registrado para fins de cálculo de IRPJ.

A fase operacional dos tramites da negociação envolve etapas em que, de fato, os pagamentos são efetivados e os registros dos montantes são destinados para cada ator envolvido no processo, seja para faturamento/pagamento ao vendedor ou comprador, recolhimento de impostos ou taxas para o governo brasileiro. Nesse estágio, tem-se o Contrato de Câmbio, a Emissão de Nota Fiscal e o Registro no Siscoserv, onde eram lançadas todas as informações comerciais por estabelecimento e por NBS (classificação fiscal do serviço), as quais serviam de base para informações tributárias e fiscais para cálculo de ISS, IRRF, e PIS/COFINS Importação, de acordo com cada negociação.

O Siscoserv foi criado com base em dois parâmetros, Módulo Venda e Módulo Aquisição. O primeiro, venda, contemplava os registros de operações de venda de serviços, intangíveis e outras operações que produzam variações no patrimônio, incluindo exportações realizadas por residentes ou domiciliados no Brasil para residentes ou domiciliados no exterior. Essas operações eram cadastradas como Registro de Venda de Serviços (RVS) e contendo informações referentes à venda (fatura comercial e/ou contrato), por residente ou domiciliado no País, de serviços, intangíveis e outras operações que produzam variações no patrimônio, a residente ou domiciliado no exterior. Por sua vez, o Registro de Faturamento (RF) abarcava informações referentes ao faturamento decorrente de venda de objeto de prévio RVS (contrato de câmbio ou nota fiscal). Já o Registro de Presença Comercial (RPC), contemplava os dados referentes às operações efetuadas por meio de Presença Comercial no Exterior relacionada a pessoa jurídica domiciliada no Brasil.

O Módulo Aquisição abrangia os registros de operações de aquisição de serviços, intangíveis e outras operações que produzam variações no patrimônio, incluindo importações, efetivadas por residentes ou domiciliados no Brasil de residentes ou domiciliados no exterior. Tais operações eram cadastradas como Registro de Aquisição de Serviços (RAS), compreendendo informações referentes à aquisição, como fatura comercial e/ou contrato, por residente ou domiciliado no País, de serviços, intangíveis e outras operações que produzam variações no patrimônio, de residente ou domiciliado no exterior. Outrossim, o Registro de Pagamento (RP) dessas operações incluía informações referentes ao pagamento relativo à aquisição objeto de prévio registro de aquisição (RAS).

Destaca-se que o responsável pelos registros RVS/RF do Módulo Venda ou RAS/RP do Módulo Aquisição do Siscoserv era o próprio residente ou domiciliado no País que mantinha relação contratual com residente ou domiciliado no exterior e contra este faturava ou era faturado 
por prestação de serviço, transferência de intangível ou a realização de outras operações que produzissem variação no patrimônio, ainda que acontecesse subcontratação de residente ou domiciliado no País ou no exterior.

Com relação aos prazos de registros para RAS e o RVS, sendo registros primários, deveriam ser realizados até o último dia útil do $3^{\circ}$ mês subsequente a contar do início da transação. O Registro de Presença Comercial no Exterior (RPC) teria que ser declarado até o último dia útil do mês de junho do ano subsequente à realização de operações, por meio de presença comercial no exterior.

No preenchimento do RAS ou RVS, os serviços, intangíveis e outras operações precisavam ser enquadradas em um dos quatro modos de prestação de serviços a seguir apresentados: comércio transfronteiriço; consumo no Brasil ou no Exterior; presença comercial no exterior; e, movimento temporário de pessoas físicas. Após este enquadramento, as transações necessitavam ser classificadas de acordo com a NBS.

Estavam desobrigados do registro no Siscoserv operações que não contemplassem mecanismos de apoio ao comércio exterior de serviços, de intangíveis e demais operações de que trata o art. 26 da Lei $\mathrm{n}^{\circ}$ 12.546, de 14 de dezembro de 2011, conforme segue:

\footnotetext{
I - As pessoas jurídicas optantes pelo Regime Especial Unificado de Arrecadação de Tributos e Contribuições devidos pelas Microempresas e Empresas de Pequeno Porte - Simples Nacional e os Microempreendedores Individuais (MEI) de que trata o $\S 1^{\circ}$ do artigo 18-A da Lei Complementar no 123, de 14 de dezembro de 2006;

II - As pessoas físicas residentes no País que, em nome individual, não explorem, habitual e profissionalmente, qualquer atividade econômica de natureza civil ou comercial, com o fim especulativo de lucro, desde que não realizem operações em valor superior a US\$30.000,00 (trinta mil dólares dos Estados Unidos da América), ou o equivalente em outra moeda, no mês (BRASIL, 2011).
}

A obrigatoriedade do registro primário (RAS/RVS) no Siscoserv ocorria somente a partir do início da transação, e não quando da ocorrência do pagamento ou faturamento das transações. Considerando o foco deste artigo, havia também a obrigação do registro por pessoa física ou jurídica, residente ou domiciliada no Brasil, que transferia o intangível, inclusive os direitos de propriedade intelectual, por meio de cessão, concessão, licenciamento ou por quaisquer outros meios admitidos em direito. Cabe ressaltar que o registro no sistema era independente da contratação de câmbio, da forma de pagamento ou da existência de um contrato formal. Estaria sujeito a multas o não registro de informações no sistema, ou preenchimento de forma indevida ou fora do prazo estabelecido para cada situação (BRASIL, 2012 $2^{\mathrm{a}}$ ).

Desde outubro de 2020, a Portaria Conjunta SECINT/RFB nº 22.091 revogou: (i) a Portaria Conjunta RFB/SCS n 1.908 , de 19 de julho de 2012, e suas alterações; e (ii) a Portaria 
MDIC $n^{\circ}$ 113, de 17 de maio de 2012, e suas alterações, que dispunha sobre a obrigatoriedade de prestação de informações de natureza econômico-comercial ao Ministério da Economia relativas às transações entre residentes ou domiciliados no Brasil e residentes ou domiciliados no exterior que compreendam serviços, intangíveis e outras operações que produzam variações no patrimônio das pessoas físicas, das pessoas jurídicas e dos entes despersonalizados (BRASIL, 2020).

De acordo com a nota conjunta do Ministério da Economia de agosto de 2020, foi anunciado o desligamento do Siscoserv de forma definitiva, por compreender que as obrigações poderiam ser acompanhadas por outros registros em sistemas oficiais. Essa decisão que, segundo a nota conjunta, integra o processo de desburocratização, facilitação e melhoria do ambiente de negócios fomentado pelo governo federal, tem a implicação da perda dessa fonte de dados relevantes e desagregados sobre o comércio exterior de serviços, especialmente dados detalhados sobre comércio internacional de direitos de propriedade intelectual.

\subsection{Nomenclatura Brasileira de Serviços, Intangíveis e Outras Operações que Produzam Variações no Patrimônio (NBS)}

O Decreto $\mathrm{n}^{\circ} 7.708 / 2012$ instituiu a nomenclatura brasileira de serviços, intangíveis e outras operações que produzam variações no patrimônio (NBS) de modo que essa nomenclatura unificasse a classificação de transações com serviços, intangíveis e outras operações que produzam variações no patrimônio das pessoas físicas, pessoas jurídicas e entes despersonalizados. Informações complementares sobre da nomenclatura foram também divulgadas por meio de notas explicativas para auxiliar sua melhor compreensão, interpretação e uso (BRASIL, 2012b).

Esta nomenclatura tem como base padrões técnicos internacionais de classificação de mercadorias e de serviços utilizado no chamado Central Product Classification, ferramenta de classificação desenvolvido pela Divisão de Estatística da Organização das Nações Unidas (ONU). A NBS abarca seis seções, contemplando 27 capítulos e abrangendo mais de 1.500 posições e subposições. Dada sua complexidade, em conjunto, foram lançadas também as notas explicativas e regras gerais para interpretação da nomenclatura brasileira de serviço.

Este classificador comercial e fiscal descreve o ativo negociado que é composto por nove dígitos que, para melhor entendimento, deve ser lido da esquerda para direita. De forma geral, o primeiro dígito apresenta a seção e indica se é um serviço, intangível ou outras operações; o segundo e terceiro dígitos determinam qual o capítulo da NBS especifica o tipo de serviço, intangível ou outra operação. Ou seja, de acordo com a regra geral de classificação essas informações iniciais têm valor apenas indicativo sobre a operação comercial. Na sequência, o quarto e quinto dígitos, 
encontram-se os textos das posições. O sexto e sétimo dígitos, em conjunto aos dígitos anteriores, configuram as subposições da subclassificação do item, e, o oitavo e o nono dígitos caracterizam o item e subitem daquela subposição.

A NBS é o meio de diferenciação de classificação para o registro das operações comerciais de serviço no Siscoserv, servindo também de base para a definição dos serviços elegíveis ao financiamento no âmbito do Programa de Financiamento às Exportações (PROEX) e na expansão dos serviços elegíveis aos Adiantamentos de Contrato de Câmbio (ACC) e Adiantamento de Cambiais Entregues (ACE). A ampliação da aplicação da NBS a outras esferas de atividades do poder público, até mesmo no campo tributário, exigiu a sua instituição formal pela Lei $\mathrm{n}^{\circ}$ 12.546/2011 (BRASIL, 2011), normativo de hierarquia mais elevada.

Portanto, ressalta-se a importância da NBS para a classificação e identificação dos serviços, além da elaboração de estatísticas necessárias para formular estratégias de investimento de recursos para fomentar o comércio exterior de serviços. Apesar do desligamento do Siscoserv, ainda será necessário classificar os serviços através do código da NBS, devido à importância da informação na Nota Fiscal de Serviço Eletrônica (NF-e).

Dessa forma, fruto dos avanços tecnológicos em ferramentas de gestão, o governo lançou no final do ano de 2019 uma ferramenta online, versão beta, que simplifica a pesquisa de serviços ou termos específicos para classificação da NBS e suas Notas Explicativas (NEBS) ${ }^{10}$.

\section{Aspectos metodológicos}

As principais bases de dados utilizadas na composição deste artigo são as estatísticas de comércio exterior de serviços, intangíveis e outras operações que produzam variações patrimoniais do Brasil disponibilizadas pelo Siscoserv e os dados do Balanço de Pagamentos divulgadas pelo Banco Central do Brasil (BCB).

No caso do Siscoserv, para garantir a homogeneidade dos dados coletados e analisados, optou-se por considerar apenas as informações do período 2014 a 2018 que utilizavam a versão 1.1 da $\mathrm{NBS}^{11}$. Essa versão é dividida hierarquicamente por capítulos e subseções chamadas de posições,

\footnotetext{
${ }^{10}$ O Trabalho realizado pela Secretaria Especial de Produtividade, Emprego e Produtividade do Ministério da Economia (SEPEC/ME) disponibilizou o portal NBS Digital, disponível por meio do endereço eletrônico http://nbs.economia.gov.br, contando com funcionalidades como, por exemplo, buscas de texto através de palavras-chave.

${ }^{11}$ Em setembro de 2018 foi publicada a Portaria Conjunta RFB/SCS n. ${ }^{\circ} 1.429$ (BRASIL, 2018) que aprovou a versão 2.0 da NBS, a qual trazia mudanças em relação à versão 1.1 da NBS que vinha sendo implementada. Com isso, os dados de 2019 foram publicados com base na NBS 2.0. Já em 8 de outubro de 2020, a Portaria Conjunta n. ${ }^{\circ}$ 22.091, da Secretaria Especial de Comércio Exterior e Assuntos Internacionais e da Secretaria Especial da
} 
subposições, itens, subitens e serviços, conforme o anexo da Portaria Conjunta RFB/SCS n. ${ }^{\circ}$ 1.820, de 17 de dezembro de 2013 (BRASIL, 2013).

A NBS 1.1 possui 27 capítulos, dos quais, dois são de interesse deste artigo por abrangerem operações sobre direitos de propriedade intelectual. Trata-se do capítulo 11, intitulado "Arrendamento mercantil operacional, propriedade intelectual, franquias empresariais e exploração de outros direitos"; e o capítulo 27, intitulado "Cessão de Direitos de Propriedade Intelectual”.

No âmbito dos direitos autorais e direitos conexos foram considerados o licenciamento, que envolve exploração patrimonial (posição 1.1103); a cessão temporária, que inclui os direitos de obras derivadas futuras (posição 1.1104); e a cessão, que envolve a transferência patrimonial (posição 1.2701).

No âmbito dos direitos de propriedade industrial foram consideradas a exploração por meio de licenciamento (posição 1.1105) e a transferência por meio de cessão (posição 1.2702) de marcas, patentes e desenhos industriais. Também foram considerados o licenciamento e a cessão de topografia de circuitos integrados (respectivamente, posições 1.1107 e 1.2704).

As operações envolvendo informações não amparadas por direitos de propriedade industrial, como contratos de Know-How e serviços que impliquem em transferência de tecnologia foram agregadas na posição 1.1110. E o chamado licenciamento e cessão de direitos relativos a informações não divulgadas (como segredos industriais) constam das posições 1.1108 e 1.2790, respectivamente.

No âmbito dos direitos sui generis estão presentes o licenciamento e a cessão de cultivares (posições 1.1106 e 1.2703); o licenciamento de conhecimentos tradicionais (posição 1.1112); e o licenciamento do acesso à recursos genéticos (posição 1.1113). Outras formas de licenciamento e cessão de direitos compõem as posições 1.1190 e 1.2790 , respectivamente.

O Quadro 2 apresenta os capítulos e as posições, com os respectivos códigos, que foram considerados operações sobre direitos de propriedade intelectual para os fins estabelecidos neste artigo.

Os dados consolidados de aquisição e venda são disponibilizados por meio dos seguintes critérios: serviços, países, estados e modo de prestação. Este trabalho apresenta uma análise dos dados de aquisição e venda geral, por estado e os principais países envolvidos. O carregamento, transformação e análise dos dados foram realizados por meio do software Power BI da Microsoft. A seção a seguir apresenta os resultados.

Receita Federal do Brasil (RFB), informou a finalização da publicação das estatísticas do comércio exterior de serviços devido ao desligamento do Siscoserv (BRASIL, 2020). 
Quatro 2 - Posições da NBS 1.1 que representam operações sobre direitos de propriedade intelectual.

\begin{tabular}{ll}
\hline Capítulo & Posição \\
\hline 1.11 Arrendamento mercantil operacional, & 1.1103 Licenciamento de direitos de autor e direitos conexos \\
propriedade intelectual, franquias empresariais & 1.1104 Cessão temporária de direitos de autor e direitos conexos \\
e exploração de outros direitos & 1.1105 Licenciamento de direitos sobre a propriedade industrial \\
& 1.1106 Licenciamento de direitos sobre cultivares \\
& 1.1107 Licenciamento de direitos sobre topografias de circuitos integrados \\
& 1.1108 Licenciamento de direitos relativos à informação não divulgada \\
& 1.1109 Licenciamento de outros direitos de propriedade intelectual não \\
& classificados em nenhuma das posições anteriores \\
& 1.1110 Contratos de transferência de tecnologia \\
& 1.1112 Licenciamento de direitos sobre conhecimento tradicional \\
& 1.1113 Licenciamento de direitos relativos ao acesso a recursos genéticos, \\
& exceto os decorrentes do conhecimento tradicional \\
& 1.1190 Outras formas de licenciamento e de cessões para exploração de \\
direitos, não classificadas nas posições anteriores \\
\hline intelectual & 1.2701 Cessão de direitos de autor e direitos conexos \\
& 1.2702 Cessão de direitos sobre a propriedade industrial \\
& 1.2703 Cessão de direitos sobre cultivares \\
& 1.2704 Cessão de direitos sobre topografias de circuitos integrados \\
& 1.2705 Cessão de direitos relativos à informação não divulgada \\
& 1.2790 Cessão de outros direitos de propriedade intelectual não \\
\hline
\end{tabular}

Fonte: Elaborado pelos autores (2021).

\section{Resultados e discussões}

A corrente de comércio internacional de serviços e outras operações do Brasil, quer dizer, a soma dos fluxos de importações e exportações, no período de 2014 a 2018, totalizou, em valores correntes, US\$ 321,06 bilhões, sendo US\$213,59 bilhões em aquisições $(66,5 \%)$ e US\$ 107,46 bilhões em vendas (33,5\%). Isso representou uma taxa de cobertura de 50,3\%, ou seja, a receita com exportações brasileiras de serviços financiou apenas metade das despesas do país com as importações de serviços. O Gráfico 3 apresenta a corrente de comércio de serviços separada por valores totais de aquisições e vendas em cada ano do período 2014-2018, juntamente com a respectiva taxa de cobertura.

Observa-se que, a despeito do quadro deficitário da balança de serviços, houve no período uma melhoria na taxa de cobertura. Isto significa que o país passou a gerar recursos com a comercialização no exterior de seus próprios serviços e outras operações para financiar uma parte maior das despesas com os serviços e outras operações adquiridas do exterior. 
Gráfico 3 - Corrente de comércio de serviços no período de 2014 a 2018.

- Aquisição $\bullet$ Venda 0 Taxa de Cobertura

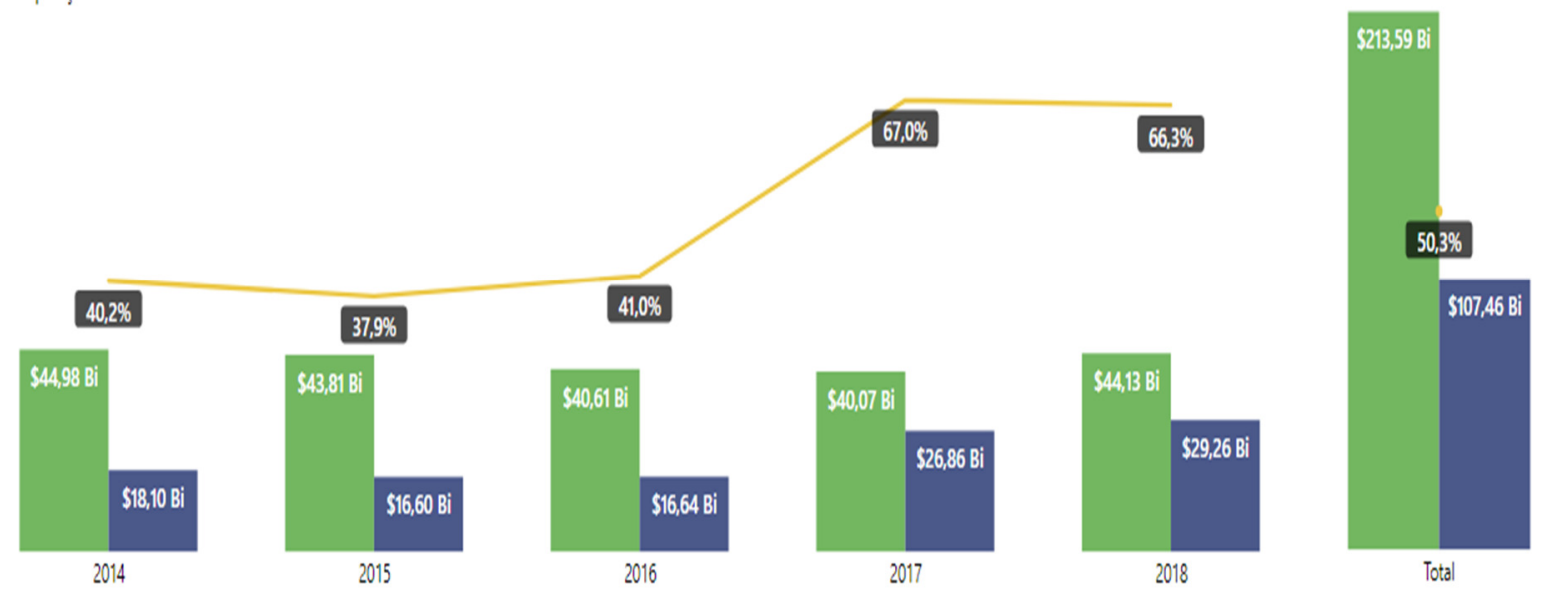

Fonte: Elaborado pelos autores (2021).

Especificamente em relação à propriedade intelectual, foco deste artigo, o Gráfico 4 apresenta a relação da corrente de comércio das operações sobre direitos de propriedade intelectual frente a corrente de comércio de serviços e outras operações. Nesse gráfico, observa-se que a participação relativa das operações sobre direitos de propriedade intelectual na corrente total de serviços e outras operações foi da ordem dos $10 \%$ no período 2014-2018.

Gráfico 4 - Corrente de comércio das operações sobre direitos de propriedade intelectual no período 2014-2018.

- Corrente de Comérico de Operaç̧eses sobre Direitos de Propriedade Intelectual (DP)) - Corrente de Comércio de Serviços 1 Percentual de Operaçòes sobre DPI na Corrente de Comércio de Serviços

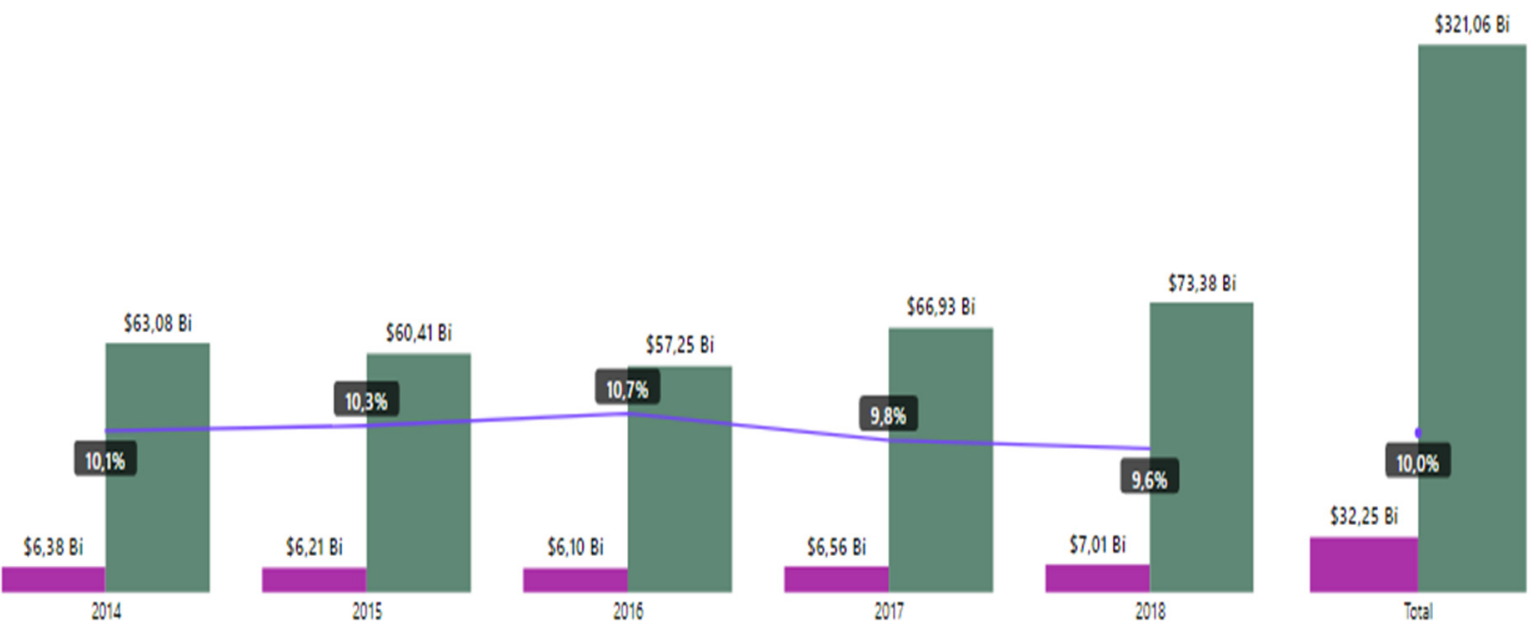

Fonte: Elaborado pelos autores (2021).

Dos US\$ 321,06 bilhões de serviços e outras operações transacionados entre o Brasil e o resto do mundo, no período 2014-2018, US\$ 32,25 bilhões referiam-se a algum tipo de operação de licenciamento ou cessão de direitos de propriedade intelectual, conforme expostos no Quadro 2. Esses dados mostram que, anualmente, entre US\$ 6 bilhões e US\$ 7 bilhões do comércio exterior 
de serviços e outras operações do Brasil estiveram relacionados à direitos de propriedade intelectual.

O objetivo deste artigo é mostrar a desagregação desses valores da corrente de comércio das operações sobre direitos de propriedade intelectual do Brasil para detalhar sua composição. Assim, o Gráfico 5 apresenta os valores do comércio de tais direitos separados por valores totais de aquisições e vendas em cada ano do período 2014-2018, juntamente com a respectiva taxa de cobertura das importações pelas exportações.

Gráfico 5 - Aquisições, vendas e taxa de cobertura das operações sobre direitos de propriedade intelectual no período 2014-2018.

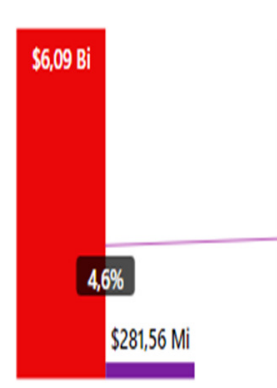

2014

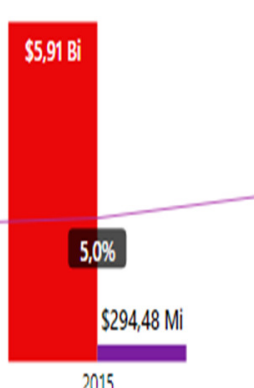

2015

Fonte: Elaborado pelos autores (2021).

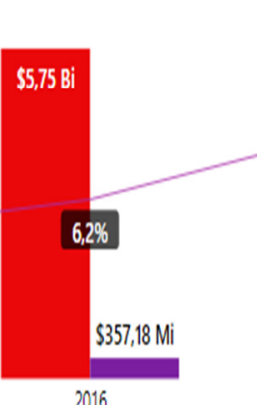

2016

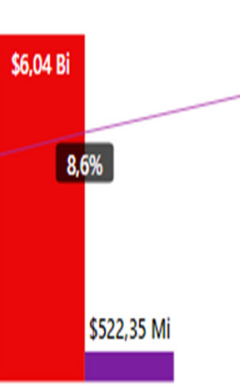

2017

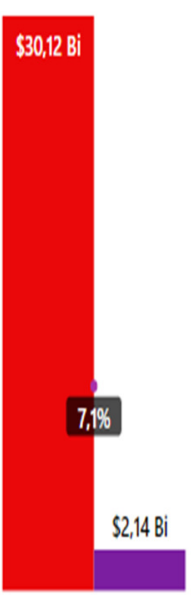

Total

Neste caso, diferentemente do comércio exterior de serviços totais, o comércio exterior de direitos de propriedade intelectual apresenta enorme desvantagem para o Brasil. A taxa de cobertura foi da ordem de $7 \%$ no período analisado, tendo variado de 4,6\% a 10,8\%. Embora anualmente as despesas com aquisição de direitos de propriedade intelectual tenham sido da ordem de US\$ 6 bilhões, apenas $7,1 \%$, em média, desse valor foram financiados com recursos oriundos de receitas de direitos de propriedade intelectual de residentes no Brasil. O que esse dado revela é a necessidade recursos de outras fontes para financiar o déficit das operações envolvendo propriedade intelectual. Ou seja, as operações sobre direitos de propriedade intelectual com o exterior podem ser entendidas como um dos fatores de déficit no balanço de serviços.

Quanto aos itens comercializados, o Gráfico 6 apresenta as dez principais operações sobre direitos de propriedade intelectual adquiridos pelo Brasil no período 2014-2018 e seus respectivos valores. 
O Gráfico 6 mostra a relevância de itens de Direitos de Autor no volume das despesas, que somaram US\$ 16,37 bilhões dentre os 10 principais serviços adquiridos, distribuídos entre programas de computador e obras audiovisuais. Mas, também, são relevantes a aquisição de KhowHow do exterior, assim como o licenciamento de marcas e patentes.

Gráfico 6 - As dez principais operações sobre direitos de propriedade intelectual adquiridas, entre 2014 e 2018, em bilhões de dólares.



Licenciamento de direitos de uso de direitos de produçào, programas de distribuiçâo ou tecnologia computador comercializaçâo de (know-how) programas de computador

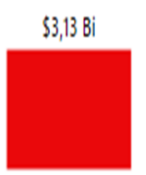

Contratos de

Licenciamento de

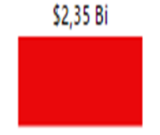
audiovisuais sobre transmissōes de programas televisivos

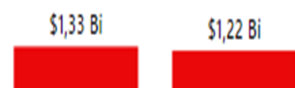

Licenciamento de Cessão de direitos direitos sobre sobre programas de sobre marcas patentes computador
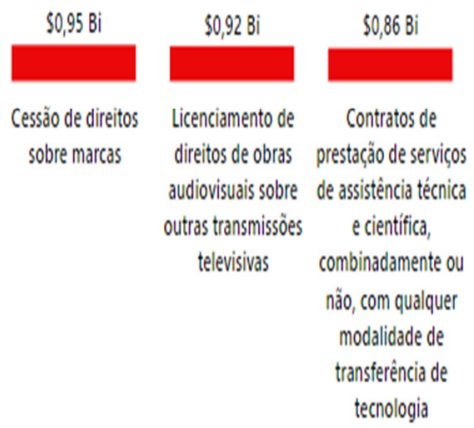

Fonte: Elaborado pelos autores (2021).

Mostrando o movimento inverso, o Gráfico 7 apresenta os dez principais direitos de propriedade intelectual vendidos pelo Brasil no período 2014-2018 e seus respectivos valores.

Gráfico 7: As dez principais operações sobre direitos de propriedade intelectual vendidas, entre 2014 e 2018, em milhões de dólares.

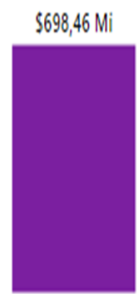

Licenciamento de

Licenciamento de direitos relativos à
informação não divulgada



Licenciamento de direitos de uso de programas de computador

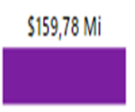

Outras formas de cessões para exploração de direitos, não classificadas nas posiçôes anteriores

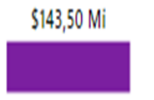

Contratos de de assistência técnica e cientifica, combinadamente ou não, com qualquer modalidade de transferência de tecnologia

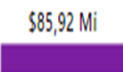

Licenciamento de outros direitos de

propriedade

intelectual não

classificados em

nenhuma das

posiçōes anteriores

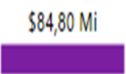

Contratos de fornecimento de tecnologia

(know-how)

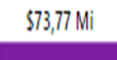

Licenciamento de direitos de outras obras audiovisuais, não classificados nos itens anteriores

\section{$\$ 68,45 \mathrm{Mi}$}

Licenciamento de direitos de autor de obras musicais ou audiovisuais sobre literomusicais outras transmissōes televisivas

Fonte: Elaborado pelos autores (2021). 
Neste caso, o destaque das vendas do Brasil vai para o licenciamento de marcas que alcançou no período valor da ordem de US\$ 700 milhões e o licenciamento de direitos relativos à informação não divulgada, com a cerca de US\$ 240 milhões. Estão presentes também na relação dos 10 itens mais vendidos ao exterior os direitos de autor relacionados tanto a programas de computador como a obras musicais e obras audiovisuais televisivas.

Gráfico 8 - Aquisições e vendas de direitos de propriedade intelectual por estado, entre 2014-2018 (em US milhões).



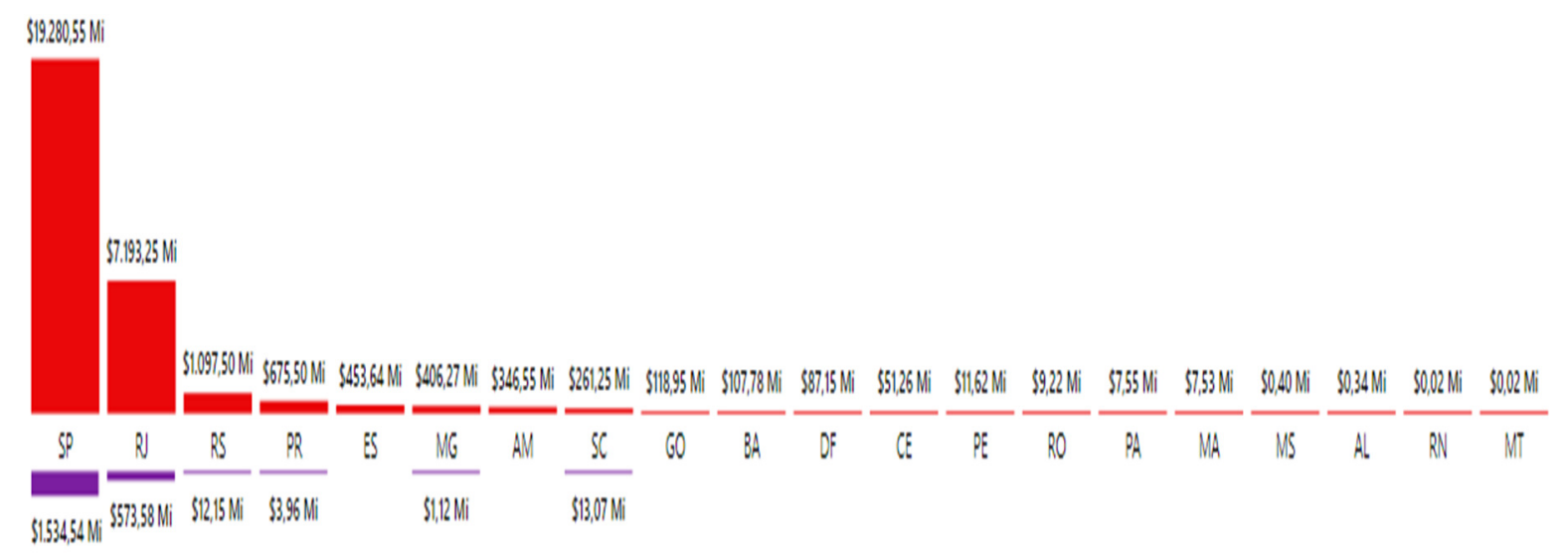

Fonte: Elaborado pelos autores (2021).

A desagregação desses dados pelas Unidades da Federação - constante no Gráfico 8 indica que sete estados (Acre, Amapá, Paraíba, Piauí, Roraima, Sergipe e Tocantins) não registraram operações sobre direitos de propriedade intelectual no período. Os demais estados e o Distrito Federal realizaram operações envolvendo esses direitos.

Cabe destacar ainda no Gráfico 8 que apenas São Paulo, Rio de Janeiro, Minas Gerais, Rio Grande do Sul, Santa Catarina e Paraná registraram receitas com a venda de direitos de propriedade intelectual no período analisado. São Paulo e Rio de Janeiro concentraram a maior parte dessa corrente de comércio, com São Paulo apresentando despesas da ordem de US\$20 bilhões e receita de US\$ 1,5 bilhões, enquanto o Rio de Janeiro apresentou respectivamente US\$ 7,1 bilhões e US\$ 0,5 bilhão. Os demais estados vendedores também registraram valores muito desfavoráveis para essas operações comerciais. Respectivamente, vê-se que o Rio Grande do Sul teve despesas de mais de US\$ 1 bilhão e, em contrapartida, apenas obteve receita de US\$12,1 milhões. O Paraná gastou US\$ 675 milhões contra uma receita da ordem US\$ 4 milhões. Minas Gerais obteve receita da ordem de US\$ 1 milhão, no entanto, suas despesas foram de US\$ 406 
milhões e, por último, Santa Catarina vendeu cerca de US\$ 13 milhões, mas, teve que comprar algo em torno de US\$ 261 milhões de direitos de propriedade intelectual.

Em suma, das 27 Unidades da Federação, conforme mostra o Gráfico 9, apenas 6 mantiveram algum registro de vendas de direitos de propriedade intelectual no período analisado, sendo 3 estados da região Sudeste (São Paulo, Rio de Janeiro e Minas Gerais) e os 3 estados da região Sul (Rio Grande do Sul, Santa Catarina e Paraná). Quer dizer, cerca de 75\% das Unidades da Federação não registraram receitas com operações sobre direitos de propriedade intelectual.

Gráfico 9 - Taxa de cobertura das operações sobre direitos de propriedade intelectual nos estados que venderam entre 2014-2018.

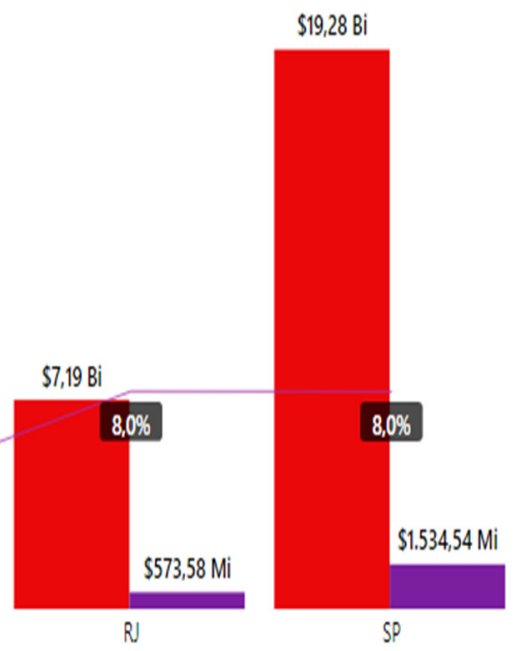

Fonte: Elaborado pelos autores (2021).

Calculando a taxa de cobertura das despesas com operações sobre direitos de propriedade intelectual desses estados que registraram receitas com essas operações, vê-se no Gráfico 9 que São Paulo e Rio de Janeiro alcançaram 8\% de cobertura e Santa Catarina 5\%. Os demais apresentaram desempenho em torno de 1\%. Isso significa que São Paulo, por exemplo, precisou financiar cerca de US\$ 18 bilhões das despesas com propriedade intelectual; Rio de Janeiro, US\$ 6 bilhões; Rio Grande do Sul, US\$ 1 bilhão; Paraná, US\$ 670 milhões; Minas Gerais, US\$ 400 milhões; e, Santa Catarina, US\$ 250 milhões.

As operações sobre direitos de propriedade intelectual e os valores relacionados a cada um desses seis estados, considerando todo o período 2014-2018, estão detalhadamente apresentadas na Tabela 1.

São Paulo é o estado com melhor desempenho relativo nas operações sobre direitos de propriedade intelectual. No entanto, cabe destacar que o principal de sua receita advém do licenciamento de direitos sobre marcas, que somou US\$ 686,86 milhões, quase $45 \%$ do total de suas receitas com operações sobre direitos de propriedade intelectual no comércio exterior. Rio de 
Janeiro, o estado que obteve a segunda melhor posição relativa, destacou-se com as receitas vinculadas ao licenciamento de direitos relativos à informação não divulgada, a qual somou US\$ 241,84 milhões, $42 \%$ do total das receitas com operações sobre direitos de propriedade intelectual.

Tabela 1 - Receitas de direitos de propriedade intelectual por estado, entre 2014 e 2018, em milhões de dólares.

\begin{tabular}{|c|c|c|c|c|c|c|c|}
\hline Direitos de Propriedade Intelectual & MG & PR & RJ & $\mathbf{R S}$ & SC & SP & Total \\
\hline Cessão de direitos de obras cinematográficas & & & $\$ 1,45$ & & & $\$ 3,79$ & $\$ 5,23$ \\
\hline Cessão de direitos de obras jornalísticas & & & & & & $\$ 1,66$ & $\$ 1,66$ \\
\hline Cessão de direitos de obras literárias & & & & & & $\$ 0,68$ & $\$ 0,68$ \\
\hline $\begin{array}{l}\text { Cessão de direitos de obras musicais e outros } \\
\text { fonogramas }\end{array}$ & & & $\$ 1,98$ & & & $\$ 4,16$ & $\$ 6,14$ \\
\hline Cessão de direitos de outras obras audiovisuais & & & & & & $\$ 6,91$ & $\$ 6,91$ \\
\hline Cessão de direitos sobre marcas & & & & & & $\$ 13,14$ & $\$ 13,14$ \\
\hline Cessão de direitos sobre programas de computador & & & $\$ 13,85$ & & & $\$ 23,93$ & $\$ 37,78$ \\
\hline $\begin{array}{l}\text { Cessão de outros direitos de autor e outros direitos } \\
\text { conexos }\end{array}$ & & & $\$ 0,74$ & & & $\$ 42,06$ & $\$ 42,80$ \\
\hline $\begin{array}{l}\text { Cessão de outros direitos de propriedade intelectual } \\
\text { não classificados nas posições anteriores }\end{array}$ & & $\$ 1,43$ & $\$ 3,92$ & & & $\$ 12,28$ & $\$ 17,63$ \\
\hline $\begin{array}{l}\text { Cessão de outros direitos sobre a propriedade } \\
\text { industrial }\end{array}$ & & & & & & $\$ 11,74$ & $\$ 11,74$ \\
\hline $\begin{array}{l}\text { Cessão temporária de direitos de autor de obras } \\
\text { publicitárias }\end{array}$ & & & & & & $\$ 2,64$ & $\$ 2,64$ \\
\hline $\begin{array}{l}\text { Cessão temporária de direitos sobre programas de } \\
\text { computador }\end{array}$ & & & & & & $\$ 9,44$ & $\$ 9,44$ \\
\hline Cessão temporária de outros direitos conexos & & & & & $\$ 1,39$ & & $\$ 1,39$ \\
\hline $\begin{array}{l}\text { Contratos de fornecimento de tecnologia (know- } \\
\text { how) }\end{array}$ & & & & & & $\$ 84,80$ & $\$ 84,80$ \\
\hline Contratos de franquia & & & & & & $\$ 3,21$ & $\$ 3,21$ \\
\hline $\begin{array}{l}\text { Contratos de prestação de serviços de assistência } \\
\text { técnica e científica, combinadamente ou não, com } \\
\text { qualquer modalidade de transferência de tecnologia }\end{array}$ & $\$ 0,16$ & $\$ 1,67$ & $\$ 42,49$ & $\$ 3,19$ & $\$ 2,20$ & $\$ 93,78$ & $\$ 143,50$ \\
\hline $\begin{array}{l}\text { Licenciamento de direitos conexos de produtores de } \\
\text { fonogramas }\end{array}$ & & & $\$ 45,35$ & & & & \\
\hline $\begin{array}{l}\text { Licenciamento de direitos de autor de obras } \\
\text { cinematográficas }\end{array}$ & & & $\$ 0,62$ & & & $\$ 18,89$ & $\$ 19,50$ \\
\hline $\begin{array}{l}\text { Licenciamento de direitos de autor de obras musicais } \\
\text { ou literomusicais }\end{array}$ & & & $\$ 60,35$ & & & $\$ 8,09$ & $\$ 68,45$ \\
\hline $\begin{array}{l}\text { Licenciamento de direitos de obras audiovisuais } \\
\text { sobre outras transmissões televisivas }\end{array}$ & & & $\$ 65,79$ & & & & $\$ 65,79$ \\
\hline $\begin{array}{l}\text { Licenciamento de direitos de obras audiovisuais } \\
\text { sobre transmissões de programas televisivos }\end{array}$ & & & $\$ 41,45$ & & & & $\$ 41,45$ \\
\hline Licenciamento de direitos de obras literárias & & & $\$ 0,03$ & & & $\$ 3,42$ & $\$ 3,45$ \\
\hline $\begin{array}{l}\text { Licenciamento de direitos de outras obras } \\
\text { audiovisuais, não classificados nos itens anteriores }\end{array}$ & & & & & & $\$ 73,77$ & $\$ 73,77$ \\
\hline $\begin{array}{l}\text { Licenciamento de direitos de produção, distribuiçãa } \\
\text { ou comercialização de programas de computador }\end{array}$ & & & $\$ 0,59$ & $\$ 0,29$ & $\$ 0,03$ & $\$ 46,52$ & $\$ 47,43$ \\
\hline $\begin{array}{l}\text { Licenciamento de direitos de uso de programas de } \\
\text { computador }\end{array}$ & $\$ 0,96$ & $\$ 0,87$ & $\$ 22,66$ & $\$ 7,31$ & $\$ 9,21$ & $\$ 150,48$ & $\$ 191,48$ \\
\hline $\begin{array}{l}\text { Licenciamento de direitos relativos à informação } \\
\text { não divulgada }\end{array}$ & & & $\$ 241,84$ & & & & $\$ 241,84$ \\
\hline
\end{tabular}




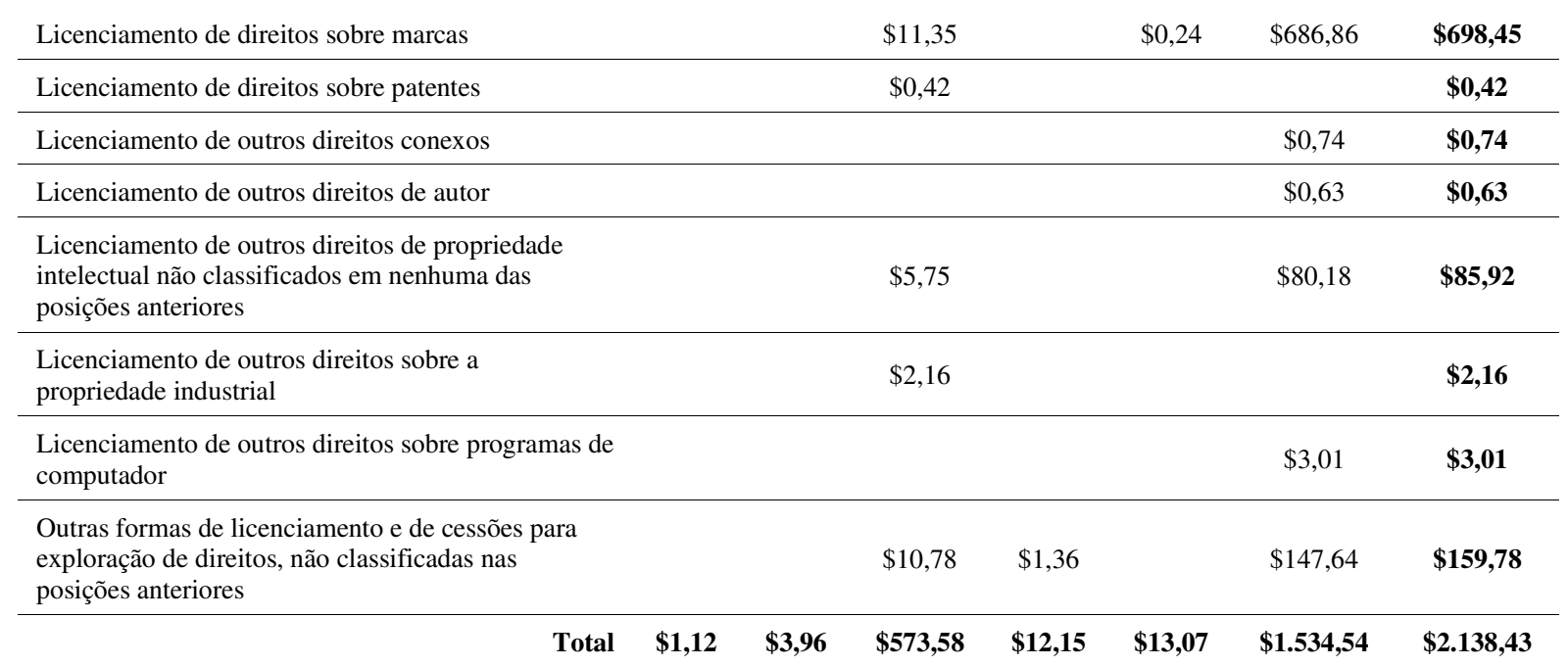

Fonte: Elaborado pelos autores (2021).

Os demais estados operaram com pouquíssimos itens de direitos de propriedade intelectual. Santa Catarina, por exemplo, obteve US\$13,07 milhões dos quais, US\$ 9,21 milhões $(70,5 \%)$ referiam-se a licenciamento de uso de direitos de programa de computador; Rio Grande do Sul obteve receitas de US\$ 12,15 milhões, sendo que US\$ 7,31 milhões (60\%) ficaram concentrados no licenciamento de uso de direitos de programa de computador; e, Paraná conseguiu obter receitas de US\$ 3,96 milhões, distribuídas, entre cessão de outros direitos de propriedade intelectual não classificados nas posições anteriores, contratos de prestação de serviços de assistência técnica e científica, combinadamente ou não, com qualquer modalidade de transferência de tecnologia além de licenciamento de uso de direitos de programa de computador. Por fim, Minas Gerais obteve receita de US\$ 1,12 milhão advindos de duas fontes, contratos de prestação de serviços de assistência técnica e científica, combinadamente ou não, com qualquer modalidade de transferência de tecnologia e licenciamento de uso de direitos de programa de computador.

Gráfico 10 - Os dez países com maior corrente de comércio de propriedade intelectual com o Brasil no período 2014-2018.

- Aquisiçōes Vendas

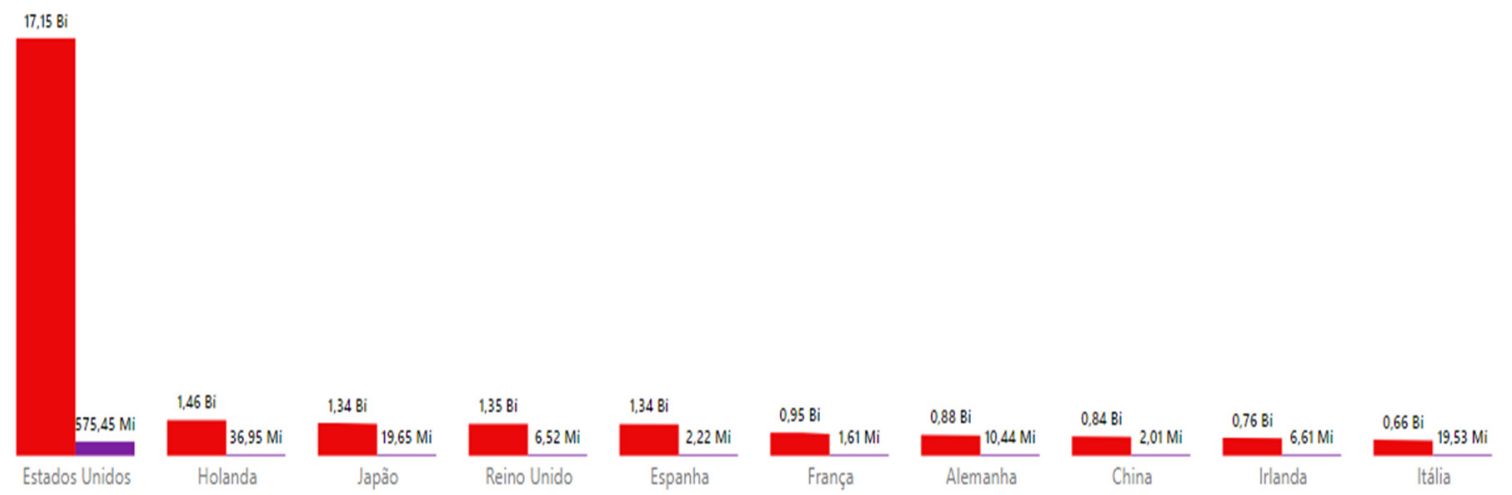

Fonte: Elaborado pelos autores (2021). 
Já os principais parceiros nas operações sobre direitos de propriedade intelectual do Brasil são apresentados no Gráfico 10, que relaciona os dez países com maior volume de operações no período 2014-2018.

Os Estados Unidos ocuparam a primeira posição de principal parceria em termos de operações de direitos de propriedade intelectual. A corrente de comércio Brasil-Estados Unidos é representada por aquisições pelo Brasil da ordem de US\$17,15 bilhões e vendas do Brasil de US\$ 575,45 milhões. Uma relação profundamente desequilibrada. A segunda posição foi ocupada pela Holanda, de quem o Brasil adquiriu cerca de US\$ 1,5 bilhão e para quem vendeu cerca de US\$ 37 milhões. Completam a relação dos 10 principais parceiros comerciais de direitos de propriedade intelectual do Brasil os seguintes países: Japão, Reino Unido, Espanha, França, Alemanha, China, Irlanda e Itália. Destaque-se que, com nenhum deles a corrente de comércio de propriedade intelectual foi favorável ao Brasil.

\section{Considerações finais}

As operações de comércio exterior do Brasil, no período 2014-2018, sobre direitos de propriedade intelectual, realizaram-se por meio dos itens relacionados no Quadro 2 deste artigo. Eles são o centro de relações comerciais e econômicas da mais alta complexidade por constituírem a forma peculiar de acesso aos principais bens da assim chamada sociedade do conhecimento, as criações, as invenções e os símbolos, fato que se realiza por meio de processos de licenciamentos, cessões, transferências e fornecimentos. Ademais, essas operações comerciais estão geralmente associadas a estratégias empresariais em busca de retorno de investimentos em pesquisa e desenvolvimento industrial, em investimentos nas indústrias de Tecnologia, Informação e Comunicação, assim como nas indústrias criativas. Em uma palavra, representam operações comerciais fortemente vinculadas a processos de inovação.

Esses dados, portanto, revelam a importância da cultura inovadora para os países e, por consequência, a capacidade de empresas residentes de participarem de processos econômicos e comerciais internacionais marcados pela apropriação de conhecimentos que se expressam por meio de negócios envolvendo direitos autorais e conexos, patentes, desenhos industriais, marcas, topografia de circuitos integrados, cultivares, softwares e serviços tecnológicos. Ressalte-se que o desafio de participação num mercado com tais características vai além da geração de inovação, envolve também a constituição de direitos por meio de procedimentos específicos para a proteção dos conhecimentos novos além de gestões visando sua exploração econômica. Isso significa desenvolver e reter competências para lidar com os processos voltados à formalização dos direitos 
de propriedade intelectual pertinentes e desenvolver estratégias de colocação de produtos e serviços inovadores no mercado baseados em conhecimentos protegidos, ambiente de intenso uso de contratos de tecnologia.

É certo que uma economia em desenvolvimento, como é o caso do Brasil, configura-se em um importador líquido de capital, fato que se expressa nos déficits na conta de serviços, incluindo a conta das operações sobre direitos de propriedade intelectual, como se pode observar também em todos os países em desenvolvimento. No entanto, as diferenças nas performances dos espaços subnacionais observadas no presente artigo a partir da perspectiva da propriedade intelectual revelam características e ritmos diferenciados de desenvolvimento nas diferentes Unidades da Federação, que não podem ser desconsideradas nas políticas públicas.

E mais, a análise dos dados aqui expostos, para evitar uma visão apologética da propriedade intelectual, levou em consideração a advertência de que "o ambiente institucional e a eficiência da operacionalidade do sistema de propriedade intelectual são condições necessárias, mas não suficientes, pois dependem das condições exógenas ao sistema de propriedade intelectual para a promoção da inovação" (TERUYA; LIMA; WINTER, 2015, p. 69). Em outras palavras, a performance dos países no comércio exterior de propriedade intelectual resulta da integração de um conjunto variado de políticas envolvendo as de ciência, tecnologia e inovação, as políticas de propriedade intelectual, as políticas industriais, assim como, as específicas de comércio exterior.

Os dados analisados, neste estudo, refletem a baixa reação do sistema produtivo nacional à introdução do rol de políticas de ciência, tecnologia e inovação pelo governo federal, e replicadas nos vários entes subnacionais no período de transição entre os séculos XX e XXI visando gerar melhores respostas aos desafios da inserção competitiva do Brasil nos novos mercados internacionais, configurados a partir da constituição da Organização Mundial do Comércio (OMC). O arcabouço legal para estimular a inovação e o desenvolvimento tecnológico representado por leis dispondo sobre contratos de franquia empresarial (Lei $\mathrm{n}^{\circ}$ 8.955/1994, substituída pela Lei $\mathrm{n}^{\circ}$ 13.966/2019), propriedade industrial (BRASIL, 1996), cultivares (BRASIL, 1997), software (BRASIL, 1998b), direitos autorais (BRASIL, 1998 ), segredo industrial (BRASIL, 2002) e topografia de circuitos integrados (BRASIL, 2007), além de toda discussão que resultou na aprovação da lei de inovação (Lei n ${ }^{\circ}$ 10.973/2004) e do novo marco legal de ciência, tecnologia e inovação (Lei $n^{\circ}$ 13.243/2016) criando melhores condições para a interação universidade-empresa associada à nova política de financiamento que criou os fundos setoriais para Ciência e Tecnologia possibilitando novos instrumentos de suporte à inovação, parecem não ter surtido efeitos relevantes para melhorar a posição relativa do Brasil no comércio exterior de serviços, particularmente no que refere às transações sobre direitos de propriedade intelectual. 
Destacou-se também nesse estudo a necessidade de tratamento conceitual mais preciso sobre a categoria "propriedade intelectual". Tal providência é necessária para que não ocorram transposições arbitrárias de sentido que possam interferir na interpretação do quadro geral de hipóteses de incidência tributária, por exemplo. Assim, não cabe confundir os "bens de propriedade intelectual", cuja caracterização pressupõe o atendimento de requisitos legais, com os respectivos "direitos" que incidem sobre esses bens, direitos esses reconhecidos legalmente como "bens móveis" e, nessa condição, passiveis de transferência por meio de contratos de licença, cessão e congêneres que compreendem, per se, "operações” originárias de variação patrimonial.

Por fim, uma das dificuldades enfrentadas na realização deste estudo foi, à despeito da importância do Siscoserv e o conjunto de dados por ele disponibilizados, a constatação de inconsistências na exposição dos dados ali consolidados. Não raro o código NBS estava associado à descrição de serviço diferente, falha material mais claramente detectada nos dados do ano de 2015, fator que impõe o necessário aperfeiçoamento dos processos de coleta, organização, legitimação e disponibilização dos dados. Neste artigo, fez-se a opção de fundamentar as análises nos dados associados aos códigos NBS para então explicitar os serviços conforme descrição oficial da NBS.

Por último, mas não menos importante, é mister reforçar a relevância e necessidade de um sistema do tipo Siscoserv que, diferentemente do balanço de pagamentos, disponibiliza dados desagregados sobre o comércio exterior de serviços por tipo, operação, valores, Unidades da Federação e países. Para efeitos de realização de estudos futuros esta é uma base de dados que oportuniza a produção de estudos, diagnósticos e cenários indispensáveis para orientação e desenvolvimento de propostas de políticas públicas de inovação e propriedade intelectual assentadas numa clara visão dos fatos.

\section{Referências}

ABREU, M. P. A ordem do progresso: dois séculos de política econômica no Brasil. 2. ed. Rio de Janeiro: GEN Atlas, 2014.

ARRABAL, A. K.; ARRABAL, O. H. B. Estatuto ontológico dos objetos de propriedade intelectual. Revista da ABPI, n. 166, p. 26-41, maio/jun. 2020.

ASCENSÃO, J. O. Direito intelectual, exclusivo e liberdade. Revista da Escola da Magistratura Federal da 5a Região, Recife, n. 3, p. 125-145, mar. 2002. Disponível em: https://revista.trf5.jus.br/index.php/esmafe/article/view/127. Acesso em: 6 ago. 2021.

BANCO CENTRAL DO BRASIL. SGS - Sistema Gerenciador de Séries Temporais - v2.1: Módulo público, 2021. Disponível em: https://www3.bcb.gov.br/sgspub. Acesso em: 6 jun. 2021. 
BARBOSA, D. B. Uma introdução à propriedade intelectual. 2. ed. Rio de Janeiro: Lumen Juris, 2003.

BRASIL. Constituição da República Federativa do Brasil de 1988. Brasília, DF: Presidência da República. Disponível em: http://www.planalto.gov.br/ccivil_03/constituicao/constituicao.htm. Acesso em: 6 ago. 2021.

BRASIL. Decreto $\mathrm{n}^{\mathrm{o}} 7.708$, de 2 de abril de 2012b. Institui a Nomenclatura Brasileira de Serviços, Intangíveis e Outras Operações que Produzam Variações no Patrimônio - NBS e as Notas Explicativas da Nomenclatura Brasileira de Serviços, Intangíveis e Outras Operações que Produzam Variações no Patrimônio - NEBS. Brasília, DF: Presidência da República. Disponível em: http://www.planalto.gov.br/ccivil_03/_ato20112014/2012/decreto/d7708.htm. Acesso em: 12 ago. 2021.

BRASIL. Lei $\mathrm{n}^{\circ} 11.484$, de 31 de maio de 2007. Dispõe sobre os incentivos às indústrias de equipamentos para TV Digital e de componentes eletrônicos semicondutores e sobre a proteção à propriedade intelectual das topografias de circuitos integrados, instituindo o Programa de Apoio ao Desenvolvimento Tecnológico da Indústria de Semicondutores PADIS e o Programa de Apoio ao Desenvolvimento Tecnológico da Indústria de Equipamentos para a TV Digital - PATVD; altera a Lei no 8.666, de 21 de junho de 1993; e revoga o art. 26 da Lei no 11.196, de 21 de novembro de 2005. Brasília, DF: Presidência da República. Disponível em: http://www.planalto.gov.br/ccivil_03/_ato20072010/2007/lei/L11484compilado.htm. Acesso em: 6 ago. 2021.

BRASIL. Lei $n^{\circ} 10.973$, de 2 de dezembro de 2004. Dispõe sobre incentivos à inovação e à pesquisa científica e tecnológica no ambiente produtivo e dá outras providências. Brasília, DF: Presidência da República. Disponível em: http://www.planalto.gov.br/ccivil_03/_ato20042006/2004/lei/110.973.htm. Acesso em: 6 ago. 2021.

BRASIL. Lei $\mathrm{n}^{\circ}$ 12.546, de 14 de dezembro de 2011. Institui o Regime Especial de Reintegração de Valores Tributários para as Empresas Exportadoras (Reintegra); dispõe sobre a redução do Imposto sobre Produtos Industrializados (IPI) à indústria automotiva; altera a incidência das contribuições previdenciárias devidas pelas empresas que menciona; altera as Leis $n^{\circ} 11.774$, de 17 de setembro de 2008, $n^{\circ} 11.033$, de 21 de dezembro de 2004, $n^{0} 11.196$, de 21 de novembro de $2005, n^{\circ} 10.865$, de 30 de abril de 2004, $n^{0} 11.508$, de 20 de julho de 2007, $n^{0} 7.291$, de 19 de dezembro de 1984, no 11.491 , de 20 de junho de 2007, $\mathrm{n}^{0}$ 9.782, de 26 de janeiro de 1999, e $\mathrm{n}^{\circ}$ 9.294, de 15 de julho de 1996, e a Medida Provisória no 2.199-14, de 24 de agosto de 2001; revoga o art. $1^{\circ}$ da Lei $\mathbf{n}^{\circ} 11.529$, de 22 de outubro de 2007, e o art. $6^{\circ}$ do Decreto-Lei $n^{\circ}$ 1.593, de 21 de dezembro de 1977, nos termos que especifica; e dá outras providências. Brasília, DF: Presidência da República. Disponível em: http://www.planalto.gov.br/ccivil_03/_ato2011-2014/2011/lei/112546.htm. Acesso em: 18 ago. 2021.

BRASIL. Lei $n^{\circ} 13.123$, de 20 de maio de 2015. Regulamenta o inciso II do $\S \mathbf{1}^{\mathbf{o}}$ e o $\$ \mathbf{4}^{\mathbf{o}}$ do art. 225 da Constituição Federal, o Artigo 1, a alínea j do Artigo 8, a alínea c do Artigo 10, o Artigo 15 e os $\$ \S 3^{\circ}$ e $4^{\circ}$ do Artigo 16 da Convenção sobre Diversidade Biológica, promulgada pelo Decreto $n^{\circ} \mathbf{2 . 5 1 9}$, de 16 de março de 1998 ; dispõe sobre o acesso ao patrimônio genético, sobre a proteção e o acesso ao conhecimento tradicional associado e sobre a repartição de benefícios para conservação e uso sustentável da biodiversidade; revoga a Medida Provisória ${ }^{\circ}$ 2.186-16, de 23 de agosto de 2001; e dá outras providências. Brasília, DF: Presidência da República. Disponível em: 
http://www.planalto.gov.br/ccivil_03/_ato2007-2010/2007/lei/L11484compilado.htm. Acesso em: 6 ago. 2021.

BRASIL. Lei $\mathrm{n}^{\circ}$ 9.279, de 14 de maio de 1996. Regula direitos e obrigações relativos à propriedade industrial. Brasília, DF: Presidência da República. Disponível em: http://www.planalto.gov.br/ccivil_03/leis/19279.htm. Acesso em: 6 ago. 2021.

BRASIL. Lei no 9.456, de 25 de abril de 1997. Institui a Lei de Proteção de Cultivares e dá outras providências. Brasília, DF: Presidência da República. Disponível em: http://www.planalto.gov.br/ccivil_03/leis/19456.htm. Acesso em: 6 ago. 2021.

BRASIL. Lei $\mathrm{n}^{\circ}$ 9.609, de 19 de fevereiro de 1998b. Dispõe sobre a proteção da propriedade intelectual de programa de computador, sua comercialização no País, e dá outras providências. Brasília, DF: Presidência da República. Disponível em: http://www.planalto.gov.br/ccivil_03/leis/19609.htm. Acesso em: 6 ago. 2021.

BRASIL. Lei $\mathrm{n}^{\circ}$ 9.610, de 19 de fevereiro de 1998a. Altera, atualiza e consolida a legislação sobre direitos autorais e dá outras providências. Brasília, DF: Presidência da República. Disponível em: http://www.planalto.gov.br/ccivil_03/leis/19610.htm. Acesso em: 6 ago. 2021.

BRASIL. Ministério da Economia. Estatísticas do Siscoserv. Brasília: Ministério da Economia, 2021. Disponível em: https://www.gov.br/produtividade-e-comercio-exterior/ptbr/assuntos/comercio-exterior/estatisticas/estatisticas-do-siscoserv. Acesso em: 3 ago. 2021.

BRASIL. Ministério da Economia. Siscoserv: manual informativo: módulo aquisição. 12a edição publicada pela portaria conjunta RFB/SCS n. 2.066 de 21 de dezembro de 2018a. Disponível em: http://receita.economia.gov.br/orientacao/tributaria/declaracoes-edemonstrativos/siscoserv-sist-integrado-de-com-exterior-int-e-outras-operacoes-prod-varpatrim/manuais-siscoserv/12aedicaomanualmoduloaquisicao_final.pdf. Acesso em: 3 ago. 2021.

BRASIL. Ministério da Economia. Siscoserv: manual informativo: módulo venda. $12^{\mathrm{a}}$ edição publicada pela portaria conjunta RFB/SCS n. 2.066 de 21 de dezembro de 2018b. Disponível em: $\quad$ http://receita.economia.gov.br/orientacao/tributaria/declaracoes-edemonstrativos/siscoserv-sist-integrado-de-com-exterior-int-e-outras-operacoes-prod-varpatrim/manuais-siscoserv/12aedicaomanualmodulovenda_versao_final.pdf. Acesso em: 3 ago. 2021.

BRASIL. Portaria conjunta $\mathrm{n}^{\circ} 22.091$, de 8 de outubro de 2020. Revoga a Portaria MDIC $\mathrm{n}^{\circ}$ 113, de 17 de maio de 2012, e suas alterações, a Portaria Conjunta RFB/SCS n 1908 , de 19 de julho de 2012, e suas alterações, e a Portaria Conjunta RFB/SCS n ${ }^{\circ} 2.066$, de 21 de dezembro de 2018. Diário Oficial da União: seção 1, Brasília, DF, n. 202, p. 17, 21 out. 2020. Disponível em:

https://pesquisa.in.gov.br/imprensa/jsp/visualiza/index.jsp?jornal=515\&pagina $=17 \&$ data $=21 /$ 10/2020. Acesso em: 31 jul. 2021.

BRASIL. Portaria conjunta RFB/SCS no 1.429, de 12 de setembro de 2018. Aprova a versão 2.0 da Nomenclatura Brasileira de Serviços, Intangíveis e Outras Operações que Produzam Variações no Patrimônio (NBS) e das Notas Explicativas da Nomenclatura Brasileira de Serviços, Intangíveis e Outras Operações que Produzam Variações no Patrimônio (NEBS). Diário Oficial da União: seção 1, Brasília, DF, n. 179, p. 20, 17 set. 2018c. Disponível em: 
https://pesquisa.in.gov.br/imprensa/jsp/visualiza/index.jsp?jornal=515\&pagina=20\&data=17/ 09/2018. Acesso em: 31 jul. 2021.

BRASIL. Portaria conjunta RFB/SCS n 1.820 , de 17 de dezembro de 2013. Aprova a versão 1.1 da Nomenclatura Brasileira de Serviços, Intangíveis e Outras Operações que Produzam Variações no Patrimônio - NBS e das Notas Explicativas da Nomenclatura Brasileira de Serviços, Intangíveis e Outras Operações que Produzam Variações no Patrimônio - NEBS, com ajustes à versão anterior, publicada pelo Decreto $\mathrm{n}^{\circ}$ 7.708, de 02 de abril de 2012. Diário Oficial da União: seção 1, Brasília, DF, n. 246, p. 187-272, 19 dez. 2013. Disponível em: https://pesquisa.in.gov.br/imprensa/jsp/visualiza/index.jsp?jornal=1\&pagina $=187 \&$ data $=19 / 1$ 2/2013. Acesso em: 31 jul. 2021.

BRASIL. Portaria conjunta RFB/SCS no 1.908, de 19 de julho de 2012a. Institui o Sistema Integrado de Comércio Exterior de Serviços, Intangíveis e Outras Operações que Produzam Variações no Patrimônio (Siscoserv) e dá outras providências. Diário Oficial da União: seção 1, Brasília, DF, n. 140, p. 31-32, 20 jul. 2012. Disponível em: https://pesquisa.in.gov.br/imprensa/jsp/visualiza/index.jsp?data=20/07/2012\&jornal=1\&pagin $\mathrm{a}=31$. Acesso em: 31 jul. 2021.

KRUGMAN, P. R.; OBSTFELD, M. Economia internacional: teoria e política. 6. ed. São Paulo: Pearson Education, 2005.

PAULANI, L. M.; BRAGA, M. B. A nova contabilidade social: uma introdução à macroeconomia. 3. ed. São Paulo: Saraiva, 2007.

SILVEIRA, N. Propriedade intelectual. 5. ed. Barueri: Manole, 2014.

TERUYA, D.; LIMA, A. A. de; WINTER, E. Papel da propriedade intelectual no processo inovativo. In: PROENÇA, A.; LACERDA, D. P.; ANTUNES JR., J. A. V; TÁVORA JR., J. L.; SALERMO, M. (orgs.) . Gestão da inovação e competitividade no Brasil: da teoria para a prática. Porto Alegre: Bookman, 2015. Cap. 4, p. 57-69. 